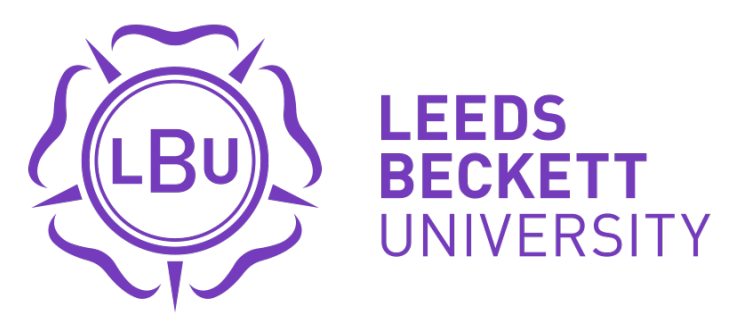

Citation:

Nasir, MA and Vo, XV (2020) A Quarter Century of Inflation Targeting \& Structural Change in Exchange Rate Pass-through : Evidence from the First Three Movers. Structural Change and Economic Dynamics, 54. ISSN 0954-349X DOI: https://doi.org/10.1016/j.strueco.2020.03.010

Link to Leeds Beckett Repository record:

https://eprints.leedsbeckett.ac.uk/id/eprint/6718/

Document Version:

Article (Accepted Version)

Creative Commons: Attribution-Noncommercial-No Derivative Works 4.0

The aim of the Leeds Beckett Repository is to provide open access to our research, as required by funder policies and permitted by publishers and copyright law.

The Leeds Beckett repository holds a wide range of publications, each of which has been checked for copyright and the relevant embargo period has been applied by the Research Services team.

We operate on a standard take-down policy. If you are the author or publisher of an output and you would like it removed from the repository, please contact us and we will investigate on a case-by-case basis.

Each thesis in the repository has been cleared where necessary by the author for third party copyright. If you would like a thesis to be removed from the repository or believe there is an issue with copyright, please contact us on openaccess@leedsbeckett.ac.uk and we will investigate on a case-by-case basis. 


\title{
A Quarter Century of Inflation Targeting \& Structural Change in Exchange Rate Pass-through: Evidence from the First Three Movers
}

\author{
Muhammad Ali Nasir, Xuan Vinh Vo \\ Leeds Beckett University, University of Economics, HCMC, Vietnam
}

\begin{abstract}
This study analyses the implications of Inflation Targeting (I.T.) for the Exchange Rate Pass-Through (ERPT) to inflation and trade balance by focusing on the first three movers i.e. New Zealand, UK and Canada. Drawing on the monthly data from October 1976 to September 2017, we employ a TVSVAR framework. Our key findings suggest that there is significant evidence of time-variation in the ERPT to inflation and trade balance in all three countries. Contrary to the notion that the ERPT to inflation has decreased under inflation targeting, in fact, there is strong evidence that if there is anything, it is the other way round. The ADF unit root test with a structural break suggests that the oscillations in coefficients for inflation show a decrease and the timing corresponds to the start of I.T. However, this coincident cannot lead to infer that the ERPT has lost its significance. There is also a considerable amount of heterogeneity in the ERPT in the under-analysis countries. Specifically, in response to the positive Real Effective Exchange Rate (REER) shock, the inflation fell in the UK and New Zealand whereas, in Canada, it had the opposite effect. On the ERPT to the trade balance, the results on the UK showed clear evidence of J-curve whereas in Canada, the impact was rather instantaneous, and the trade balance quickly deteriorated. In New Zealand, the trade balance also showed deterioration in response to the REER shocks, although comparatively there was milder response than Canada and the UK. Our findings have profound implications for monetary policy formulation under I.T. regimes and the influence of ERPT on price stability and external balance.
\end{abstract}

Key Words: Inflation Targeting, Pass-through, Exchange Rate, Trade Balance, J-curve, Monetary Policy, TVSVAR Model.

JEL Classification: E31, E52, E61, F31, F32. 


\section{Introduction}

Price stability has almost always been the focus of monetary policymaking, particularly since the periods of great inflation in the 1970-80s. This emphasis had been at its greatest around the period of great moderation where the sole of purpose of the monetary policy was price stability, and if this goal is achieved everything was expected to find the place like pieces of the jigsaw. Despite the change in the tone and stance of monetary authorities in the Post-Global Financial Crisis (GFC) era where the financial stability has also become the responsibility of monetary authorities, price stability remained their core function. Keeping the objective of price stability in focus, the strategy of explicit inflation targeting was adopted by the Reserve Bank of New Zealand (RBNZ) in the 1990s. Soon after RBNZ, the Bank of England and Bank of Canada followed the suit and as it stands, there are about 28 countries which have adopted the strategy of explicit inflation targeting, (IMF, 2017). Having an explicit inflation target as a part of monetary policy framework acts as a nominal anchor, once this anchor is laid, the monetary policy actions can then steer the inflation to its target in stipulated period e.g. medium-long term. Concomitantly, one of the major advantages of inflation targeting is what one may call "doubleedge effect", putting simply; it combines the characteristics of both "rules" and "discretion" in the monetary policy framework. This is a prima facie manifestation of "constrained discretion"". The inflation targeting requires some degree of independence in terms of instrument setting as well as the willingness and the ability of the monetary authority to focus on inflation as the prime objective.

The start of inflation targeting, pioneered by New Zealand (followed by Canada, UK et al.) was also the period for the beginning of the great moderation. As it is prima facie evidenced in Figure 1, since the start of the inflation targeting, the inflation has been mostly low by historical standards. So, shall we consider it as a fruit of "good policy" or mere coincidence with the great moderation and hence "good luck"? In this regard, Beaudry and Ruge-Murcia (2017) argued that although non-targeting countries have also achieved macroeconomic stability, in comparison with the other countries (US, UK, NZ, Sweden and Australia) the strategy has been comparatively more successful in Canada. In a recent study, Yetman (2017) argued that the explicit inflation-targeting regime (Canada) provides for less uncertainty about future monetary policy actions than the US where there was no explicit numerical inflation target (until 2012) to anchor expectations.

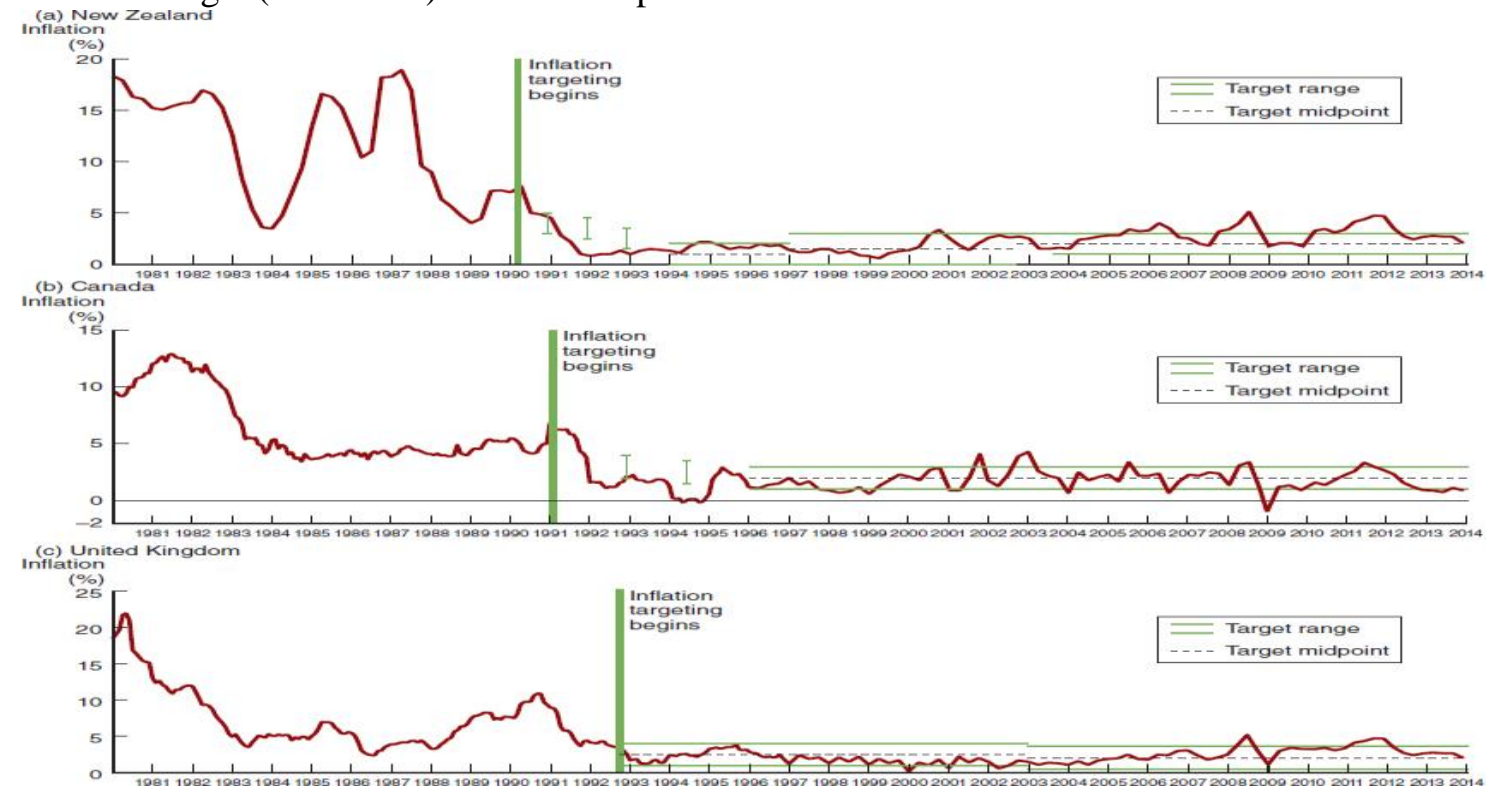

Figure 1 Inflation Rates and Inflation Targets for New Zealand, Canada, and the United Kingdom, 19802014; Source (Mishkin, 2016).

\footnotetext{
${ }^{1}$ Term coined by Bernanke (2003) in his famous speech ""Constrained Discretion" and Monetary Policy".
} 
By influencing the inflation as well as inflation expectation, the credible inflation targeting shall harbour the price stability. According to its proponents, there are numerous benefits of inflation targeting, for instance, simplicity, transparency, accountability, anchoring of inflation expectations and most importantly price stability. However, there are also some critiques of inflation targeting which argued that the strategy of inflation targeting has crucial limitations (see Nasir et al 2020a for a detailed insight into this debate). Concomitantly, the debate continues, yet there are two implications one shall consider at this juncture a) there are various other factors to take into account if we are considering the consequences of the inflation targeting b) impact of inflation targeting could materialise differently among various economies as well as on different aspects of the same economy. As a corollary of this notion, one aspect of inflation targeting which is fairly underappreciated, yet, fundamentally important for the monetary policy formulation as well as its success is the "Exchange Rate Pass-Through (ERPT)" i.e. responsiveness of prices to exchange rate dynamics. Undoubtedly, exchange rate fluctuations have great significance for the competitiveness of an economy, its financial sector as well as ability and cost of servicing the debts, denominated in the foreign currency. Nonetheless, an important aspect of the exchange rate movement is ERPT. Therefore, even if the monetary authority is not directly controlling the rate of exchange of domestic currency, the exchange rate dynamics will still have profound implications for the monetary policy framework through inflation channels. The effect of exchange rate moment is a "critically important determinant" of the timing of monetary policy actions (Forbes, 2016). Despite, the profound importance of ERPT, and a great amount of research and empirical evidence some of which we will acknowledge in the next section, in Forbes (2016, p.3) words "we have surprisingly poor understating of exactly how exchange rate movements affect inflation". Similarly, Ha et al (2019) have argued that the ERPT to inflation varies considerably across countries and is timevariant. Furthermore, the ratios of ERPT are lower in the countries which have a flexible exchange rate regime and have adopted inflation targeting. A crucial factor which has made the understanding even more difficult is the time-variation of the association between exchange rate movements and price dynamics. Furthermore, one aspect which also requires special consideration and also a motivation for this study is the intuitional design of monetary policy framework and its implications for the ERPT. In simple words, whether and how the framework of explicit inflation targeting can influence the association between exchange rate dynamics and rate of inflation?

In the light of economic theory, the dynamics of the exchange rate are not only important for the price stability but without any doubt, they have profound implications for a country's external (trade) balance. On this notion, we can go back two and a half centuries to Hume's (1742) price-specie flow mechanism argument. However, effects of exchange rate dynamics on trade balance are contingent on the imports and exports elasticities and whether they add up to a value greater than unity, a phenomenon often referred as the Marshall- Learner condition (Bahmani-Oskooee and Ratha, 2004). Empirical evidence suggests that depreciation of currency shall harbour significant improvement in the external balance of both developed and developing countries (Bahmani-Oskooee et al., 2013, Bahmani-Oskooee, 2016; Yildirim and Ivrendi, 2016). Although there are some studies which reported the absence of such a mechanism, for instance, Rose and Yellen (1989) and Rose (1991) failed to find a significant impact of exchange rate dynamics on the trade balance. Nonetheless, if we are considering the time-varying aspect of ERPT to inflation, it would be very logical to assume that there could be time-varying implications of exchange rate dynamics for the trade balance. As the fundamental of the economies competitiveness, for instance, terms of trade, innovation, productivity as well as trading channels do change in the face of time, the association between the exchange rate and trade balance may well be time-variant.

An important contribution this study is endeavouring to make to the debate on ERPT is the consideration of time-variation. On this issue, Forbes (2016, p. 14) argued that "One assumption that is traditionally made in many institutions when analysing pass-through is that it is fairly stable over time - at least within a given country. This assumption has continued to be used in most analyses of pass-through, despite it being challenged in a number of studies over the years - including at the Bank of England". New Zealand, UK and Canada are the economies where inflation has been explicitly targeted for over a quarter of a century, and on this aspect, there is a notion that the inflation targeting could diminish the impact of the exchange rate on inflation (See, Edwards, 2007, Junior 2007). However, the empirical 
evidence suggests that the ERPT to inflation has been in fact increasing in recent years (See Forbes 2016, Forbes et al 2017). In this study, we will put this notion to the empirical testing and see if the significance of ERPT for inflation as well as external balance have diminished under the inflation targeting. One more novelty of this study is the consideration of the ZLB. Given that the analysis carried out by Forbes et al, (2017) reported that "exchange rate movement caused by the monetary policy shocks consistently correspond to significantly higher estimates of pass-through than demand shocks", hence it raises a question that since monetary policy is constrained at a proximal ZLB for the last 11 years (by the writing of this paper), what implications it has for the ERPT? Contextualising on these aspects together, we analysed the ERPT to inflation and trade balances of the first adopters of inflation targeting regime ${ }^{2}$ (New-Zealand, UK and Canada) in a time-varying empirical framework. In so doing, we employed a TVSVAR framework on the data from October 1976 to September 2017. To start with, the ADF unit root test with a structural break is also applied inflation dataset. The coefficients showed the beginning of a period of tranquillity which corresponded with the start of inflation targeting. With regards to the ERPT, our key findings suggest that there was significant evidence of time-variation in the ERPT to inflation and trade balance in all three countries. Contrary to the notion that the ERPT to inflation has decreased in the inflation targeting economies, in fact, there is strong evidence that it is the other way around. There is also a considerable amount of heterogeneity in the ERPT to inflation in the under-analysis countries. Specifically, in response to the positive Real Effective Exchange Rate (REER) shock, inflation fell in the UK and New Zealand, however, in Canada, it had the opposite effect. On the ERPT to the trade balance, the UK showed clear evidence of J-curve, whereas in Canada, the impact was contemporaneous and trade balance quickly deteriorated. In New Zealand trade balance also showed deterioration in response to the REER shocks, although comparatively there was milder response than Canada and the UK. Our findings have profound implications for monetary policy formulation under inflation targeting regimes and influence on the ERPT to inflation and trade balance.

Paper proceeds as follows, $\S 2$ contextualises the core argument of the subject treatise by critically discussing the nexus between inflation targeting, ERPT and Trade Balance in the light existing evidence, $\S 3$ sets out and briefly describes the layout of TVSVAR framework, $\S 4$ will present the findings and in $\S 5$ we will draw conclusion and discuss the policy implications.

\subsection{Inflation Targeting \& ERPT}

Dawn of inflation targeting broke on New Zealand's soil and soon after was followed by the UK and Canada. However, until very recently, some of the biggest players, prominently the US Fed and European Central Bank (ECB) did not show a much zeal toward adopting this framework (Riboni and Ruge-Murcia, 2018). Perhaps, one of the missing ingredients was the willingness and appetite of the central bank to do so. Nonetheless, there is no doubt that there were favourable views about inflation targeting among prominent US economists. For instance, Bernanke et al (2001) in their comprehensive study, strongly argued that the inflation targeting has clear advantages and the US Federal Reserve and the European Central Bank (ECB) should adopt the inflation targeting ${ }^{3}$. In terms of advantages, they argued that the simplicity and openness of inflation targeting made it far easier for the public to understand the intent and effects of monetary policy. Perhaps, there is also an increase in the policymakers' accountability on one hand and flexibility of accommodative "discretionary," monetary policy actions on the other. Drawing on the evidence from nine countries ${ }^{4}$ it was argued that inflationtargeting countries have typically seen lower inflation, lower inflation expectations, and lower nominal interest rates, and shocks to the price level have less of a "pass-through" effect on inflation.

\footnotetext{
${ }^{2}$ See Haldane (1995) for a detailed insight.

${ }^{3}$ In fact, they followed the advice (or in case of Fed order).

${ }^{4}$ Germany and Switzerland (employed a form of inflation targeting focused on money), Australia, New Zealand, Canada, Sweden, Israel, Spain and United Kingdom.
} 
An inflation-targeting framework with well-anchored inflation target is supposed to be helpful in delivering a moderate and stable rate of inflation (Obstfeld, 2014). In this context, transparency is one of the major benefits of explicit inflation targeting. Perhaps, it was the effort towards a higher degree of transparency that the Bank of England pioneered the "Inflation Report" in 19935. Almost two decades later, similar ambitions led the Federal Reserve to make its views and approach to inflation more explicit and start producing "Statement on Longer-Run Goals and Monetary Policy Strategy". Williams (2014) argued that in the Post-GFC world, the explicit, as well as implicit inflation targeting has been successful in bringing price stability and anchoring inflation expectation. However, there are two vital challenges, the constraint of the Zero Lower Bound (ZLB) on nominal interest rates and the appropriate role of monetary policy in supporting financial stability. On the issue of ZLB, an important aspect which this study is also focusing on is its implications for the ERPT, given that at the ZLB the monetary policy is constraints, it may influence credibility or at least the ability and perceived ability of the monetary policy to act to stabilize the inflation and output, though evidence is not conclusive (see Ruge-Murcia, 2002, Ruge-Murcia, 2010; Nasir, 2017). We will reflect on this aspect later and it would also navigate our empirical endeavour, for now, reverting back to the effectiveness of inflation targeting, the issue is still debatable (contrast, see Nasir et al 2020 for discussion). Perhaps this is the reason that the inflation targeting framework is not universally applied. In the Post-GFC era and monetary policy formulation, the debate got more inflamed (see, Frankel, 2012; Reichlin and Baldwin, 2013). In a nutshell, the success of inflation targeting is debatable as the empirical evidence is inconclusive and contrasting. Yet, the focus of this treatise is on the implication of inflation targeting for the ERPT to inflation and trade balance, in the face of time variation and hence, during those instances when the monetary policy is in proximal ZLB.

\subsection{Inflation \& ERPT}

There is a huge amount of literature confirming the substantial effects of the ERPT on inflation which also shows varying degrees of impact ${ }^{7}$. The concept of ERPT is simple yet, its importance for the economy and hence for the monetary policy is paramount. This significance has made it an important venue for research and exploration. Apparently simple, the ERPT is quite complex phenomena hence it is difficult to comprehend and predict the way it materialises (see Krugman, 1987; Dornbusch, 1987; and Klein, 1990). In this regard, a number of studies focusing on industry/micro-level data suggested that the ERPT could be influenced by a number of factors including the import/export composition, nominal rigidities, currencies of pricing, market up adjustment, dispersion of price changes and competition in the final goods ${ }^{8}$.

Debunking some of the misunderstandings which led to under-appreciation of the ERPT, Forbes (2016) argued that assumptions like ERPT are greater in the sector with a greater import content and the sector that is more tradable and intentionally competitive does not hold their grounds in the face of evidence. Nonetheless, the magnitude of the ERPT continues to change-over-time. On the aspect of time-variation and its direction, there is limited yet contrasting evidence. For instance, on the UK and US, Mumtaz et al. (2006) and Marazzi et al (2005) reported that the ERPT to import prices had decreased significantly. Similarly, focusing on Switzerland, Stulz (2007) documented that pass-through has fallen, while contrarily, Fleer et al. (2015) documented that it has increased sharply. In evidence from the Euro area, Ozyurt (2016) reported a decline in the ERPT in the 1990s, whereas Jasová et al (2016) reported changes

\footnotetext{
5 Inflation reports and details on the Bank of England Monetary framework are available at https://www.bankofengland.co.uk/monetary-policy

${ }^{6}$ See Federal Reserve (2018).

${ }^{7}$ For instance See Menon (1995), Goldberg and Knetter (1997), , Campa and Goldberg (2005), Choudhri and Hakura (2006), Mumtaz et al, (2006), Bhattacharya et al (2008), Burnstein and Gopinath (2013), Forbes (2015), Forbes (2016), Yildirim and Ivrendi (2016) and Nasir and Simpson (2018).

${ }^{8}$ Study by Forbes et al (2015) acknowledged and complied this evidence.
} 
in pass-through in developing and developed countries since the $\mathrm{GFC}^{9}$. In the most recent cases, capitalising on Forbes et al (2015) framework and focusing on Euro countries (Germany, France, Italy and Spain), Comunale and Kunovac (2017) showed that the ERPT to inflation in the euro area is timevariant. Whereas, a recent study by Nasir and Simpson (2018) on the UK suggested rather an increase of pass-through magnitude in recent years. Perhaps, it was this contrasting evidence and ambiguous nature of ERPT that led Forbes (2016) to argue that:

"To summarize, recent evidence from the UK supports results from several countries at different time periods-that pass-through appears to change over time. Given that this point has been made in the past, it is unclear why it has not been incorporated in mainstream thinking and analysis on pass-through. This may partly reflect the impossibility of forecasting pass-through if it changes over time - and especially if one does not fully understand why it changes" (Forbes, 2016 p. 31-32).

Clearly, there is an element of Time variation as well as a question on the direction of this variation. On this aspect, there is evidence of change in the ERPT to inflation, during and post GFC (Forbes, 2016 and Forbes 2015b). Nonetheless, the timing of shock in terms of the economy's position on the business cycle at the point of impact is also critical to consider (Forbes, 2016). There are also a number of studies which reported country-wise differences in the ERPT to reflect on the importance of structural differences across countries (for instance, contrast Gopinath (2015), Stulz (2007) and Fleer et al (2015), Forbes (2015), Fisher (2015) and Ha et al (2019). The depiction of the country-wise difference is evident in Figure 2:

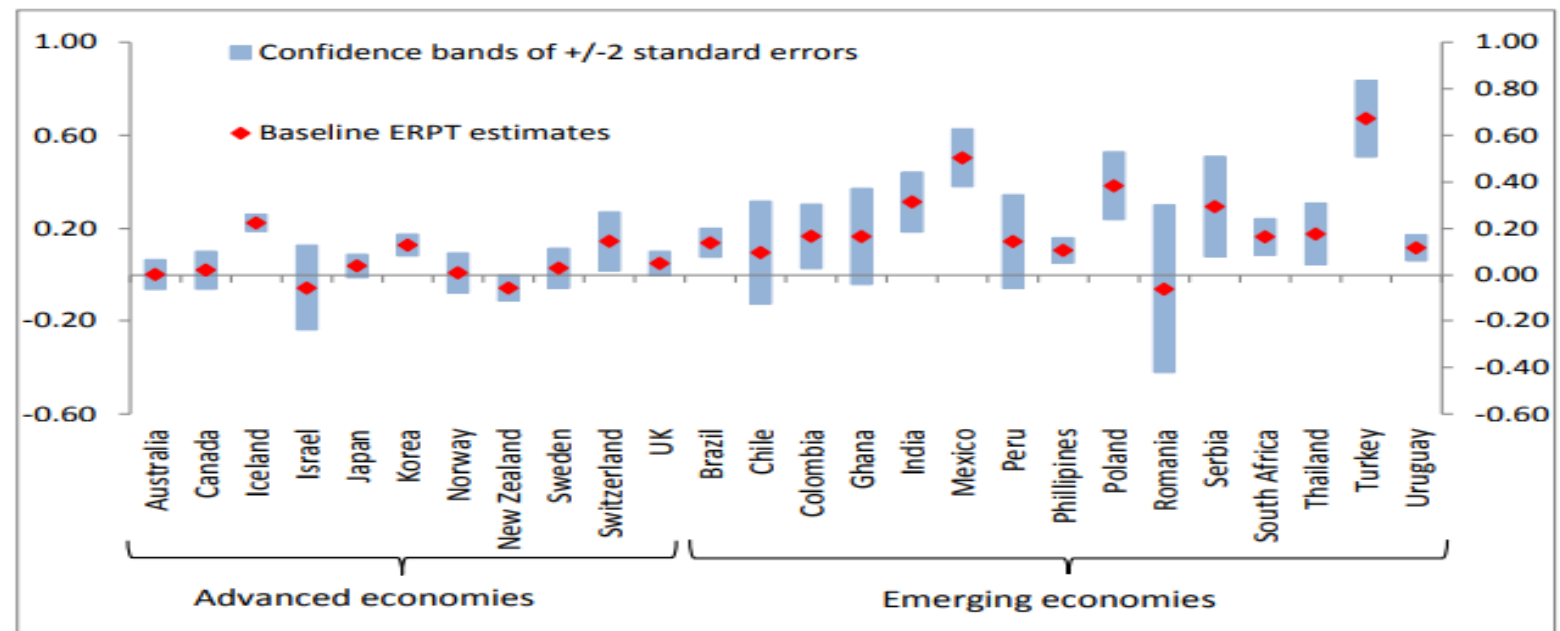

Figure 2: Exchange Rate Pass-through by country (Source; Forbes et al 2017)

In a rather recent and fairly comprehensive study, Forbes et al (2017) found differences among the countries attributed to the structure of their economies as well as differences in the degree of passthrough associated with the nature of the shock. It made them conclude that in an effort to understand how the exchange rate movement will affect inflation, we shall take into account the structure of the economy as well as the source of the shock. This line of reasoning has another dimension, if the adoption of inflation targeting influences the inflation as well as inflation expectation, then logically adoption of such a strategy shall also influence the ERPT to inflation? We will revert to this point in the next section. An important point to note at this juncture is that the ERPT to inflation is time-variant and there are country wise differences, a clear depiction of this notion is also explicit in Figure 3.

\footnotetext{
${ }^{9}$ Jasová et al (2016) also urged that the non-linearties should be taken into account while considering the ERPT, an aspect the subject study will consider.
} 

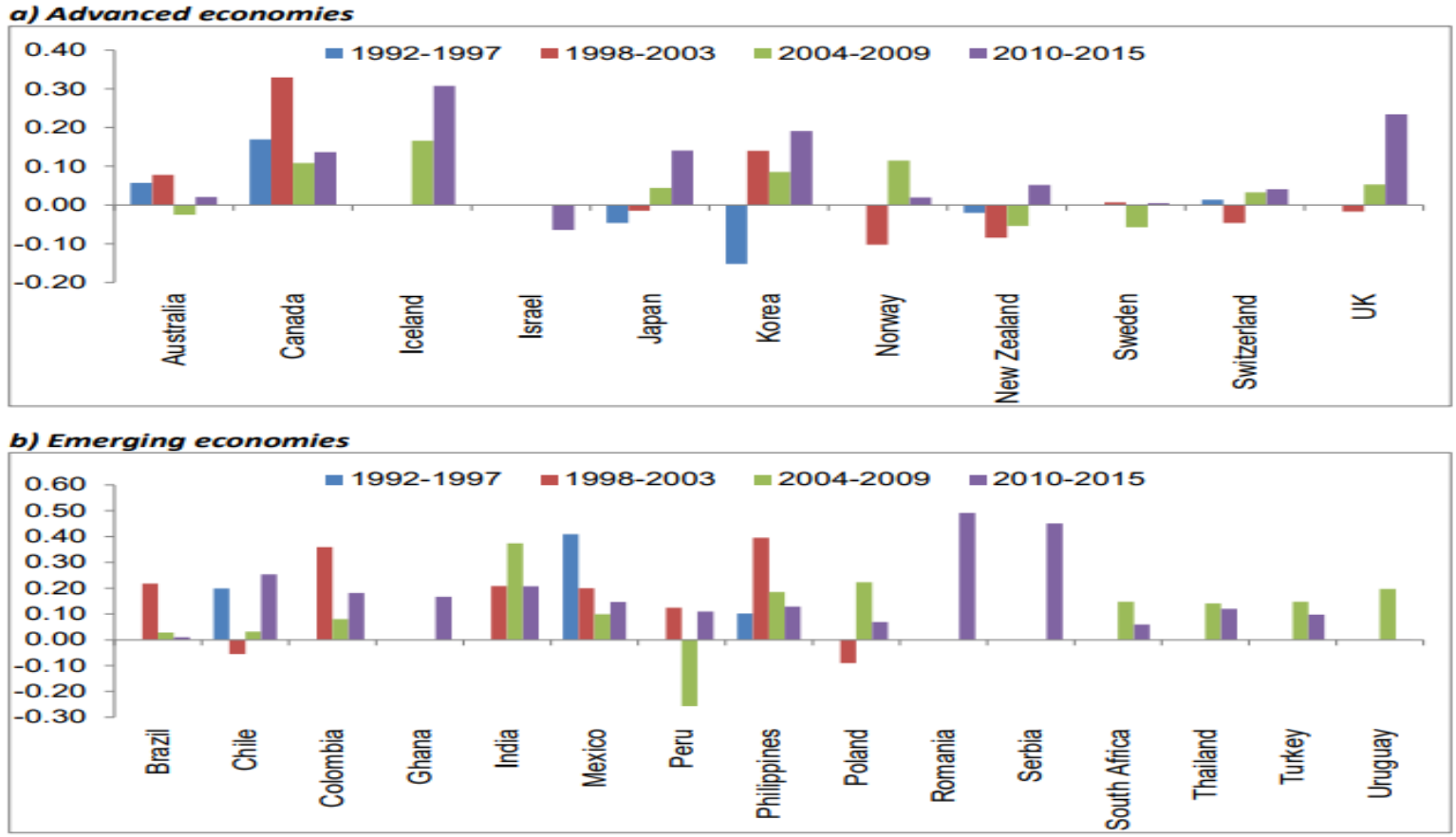

Figure 3: Pass-Through estimates over four 6-year periods (Source Forbes 2017).

Whilst the time variation and country-level heterogeneity in the ERPT to inflation poses challenges to the understanding of the implications of exchange rate dynamics, it also opens a new venue for explorations. Exchange rate movements are an important determinant of the inflation and obviously, monetary policy setting. High and volatile ERPT can pose challenges to monetary policy in her efforts towards the attainment of inflation target (Fraga et al, 2003). The credibility of the central bank is important in perusing the objective of price stability (see Taylor, 2000; Gagnon and Ihrig, 2004; Choudri and Hakura, 2006; Caselli and Roitman, 2016 and Carriere-Swallow et al. 2016). For the same reason, it is important to consider what implications inflation targeting strategy has for the ERPT to inflation. Often, there is a notion of anchoring inflation expectations through inflation targeting. In the context, of ERPT to inflation expectations, Nasir et al (2020a) reported significant evidence of ERPT to inflation expectations in the UK and New Zealand. Whereas, Nasir et al (2020b) report significant evidence of ERPT to inflation expectations in the small open economy of the Czech Republic which is also inflation targeting regime. In a comparative study on the inflation targeting and non-targeting economies of Scandinavian countries, Nasir et al (2020c) reported that the ERPT to inflation expectations was found in Norway, Sweden and Denmark. This implies that the notion of anchoring inflation expectations through inflation targeting so that the ERPT could be tamed does not hold much water. Hence, the ERPT to the inflation as well as trade balance may still be valid under inflation targeting.

\subsection{Trade Balance \& ERPT}

Exchange rate dynamics have important implications for the external (trade) balance of a country and its global competitiveness, as a weaker currency makes the exports more attractive to foreigners and vice versa for the domestic consumers. Subject to the Marshall-Learner condition, exchange rate depreciation (appreciation) can lead to improvements (deterioration) of the balance of trade. Analogous to the ERPT to inflation, the response of trade balance is not that straightforward either, and one shall not always expect an instantaneous improvement in trade balance following a depreciation. Empirical evidence suggests that there is a $J$-curve that prevails (see, Bahmani-Oskooee and Ratha, 2004; and Bahmani-Oskooee et al. 2018). In simple words, before any improvements, initially, exchange rate depreciation leads to a deterioration of trade balance. Similarly, Bahmani-Oskooee (1991) analysis on LDCs reported that devaluation often improves the trade balance in the long run, while in their study 
on the trade balances of the developed countries, Lane et al (2002) reported negative effects of exchange rates appreciation ${ }^{10}$. As the ERPT effects the prices of imports (Ali and Anwar 2016), concomitantly, the improvements in the trade balance are also results of expenditure switching and expenditure changing policies by the household and firms (Yildirim and Ivrendi, 2016). Contrarily, some of the studies focusing on the exchange rate and trade balance could not find a significant link (Rose, 1990) or evidence of J-Curve (Rose and Yellen, 1989). Analysis by Rose (1991) of the Post-Breton Woods period (1974 - 86) using data of five OECD (UK, Canada, US, Germany, Japan) countries reported lack of significant evidence of exchange rate affecting the trade balance. Some studies also suggest heterogeneity in the response of the economy to the exchange rate shocks (e.g. see Boyd et al (2001) on the eight OECD countries) ${ }^{11}$.

One may object that on the debate on inflation targeting and ERPT, where does the trade balance stand? However, the nexus between ERPT to inflation and trade balance shall not be seen in isolation. The reasoning and logic of this position are embedded in the notion that in the floating exchange rate system, exchange rate variability is an important factor contributing to inflation variability (Bahmani-Oskooee, 1991). To say the least, the monetary authority of an open economy adopting an inflation targeting strategy will be myopic, if in its analysis and treatment of ERPT, the external balance and implications it may have are condoned. Beyond any reasonable doubt, unlike monetary targeting, inflation targeting is not dependent on the stability of the demand for money and, unlike foreign exchange targeting, it does not require direct foreign exchange market intervention, huge changes to the interest rates, and the loss of monetary authority's independence (Mishkin, 1998; Canarella and Miller, 2016). In terms of stabilisation and targeting of the exchange rate and inflation, there are suggestions and indications towards a symmetric relationship (see Gerlach, 1994) ${ }^{12}$. However, there is also an argument that a managed exchange rate environment delivers a stronger nominal anchor to inflation shock and concomitantly helps in the inflation targeting (Pourroy, 2012). Some studies, for instance, Goldfajn and Muinhos (2003), Gagnon and Ihrig (2004) and Edwards (2007) have suggested that inflation targeting could lead to a decline in the ERPT to inflation. Junior (2007) argued that while the ERPT could decline due to the adoption of Inflation Targeting, it should be not inferred that the ERPT has become nonexistent, particularly in the long run. Some scholars have tried to explain the fall in ERPT and suggested that the ERPT might have been declined due to the increased credibility and gains one may associate with the inflation targeting which can keep the inflation expectations low after depreciation (Mishkin and Savastano (2001), Eichengreen (2002) and Schmidt-Hebbel and Werner (2002). However, recent studies by Nasir et al (2020a, 2020b and 2020c) suggest that it is not the case and there is ERPT to inflation expectations. Nonetheless, Forbes (2016), Forbes et al (2017), Nasir and Simpson (2018) suggests an increase in ERPT in recent years. Evidence on the implications of the source of exchange rate movements on ERPT presented by Forbes et al (2017) suggested that the monetary policy shocks induced exchange rate movements' leads to the highest magnitude of ERPT to inflation. A very important point to note at this juncture is that the monetary policy in the under-analysis countries has either been at or very close to the ZLB over the last decade. An intuitive question arises that what implications it may have for the ERPT? In specific to under analysis economies i.e. New Zealand, UK and Canada, the exchange rate is not managed but inflation has a statutory target. Therefore, the monetary policy could be off-guard to exposure of inflation and inflation expectations to the exchange rate dynamics, unless the nominal anchors i.e. inflation target can compensate for the absence of an exchange rate anchor. Flexible exchange rates could be more effective in the adjustment of external imbalances (Ghosh et al, 2013). Yet, in the given exchange rate regime and inflation targeting regime, the question we are concerned with is that what implications ERPT can have for inflation and trade balance in the subject economies. Nonetheless, how has the association among the under-analysis

\footnotetext{
${ }^{10}$ In recent studies, Bahmani-Oskooee et al (2018) and Nasir and Leung (2019) reported asymmetries in the impact as well as duration (also see Aftab et al, 2016).

${ }^{11}$ Canada, France, Germany, Italy, Japan, Netherlands, UK and US.

${ }^{12}$ Increase in interest rate to stabilize the falling exchange rate can also help to curb the inflation.
} 
entities changed over-time, what implications ZLB has and how ERPT has been influenced by the strategy of inflation targeting pioneered by these countries more than a quarter of a century ago.

\subsection{Methodology}

To account for the time-varying aspect of ERPT to inflation and trade balance, we employed a TVSVAR framework. In so doing, we drew on the seminal work by Primiceri (2005) and Del Negro and Primiceri (2015) ${ }^{13}$. The novelty and rationale of this choice are that in this framework, coefficients and entire variance-covariance matrix of the shocks are allowed to vary over time. This is particularly important when our aim is distinguishing the changes in the transmission mechanism of the ERPT to inflation and trade balance from the changes in the typical size of the exogenous innovations in Pre and Post inflation targeting.

\subsection{The TVSVAR Model}

Employed TVSVAR model comes with the benefit of drifting coefficients that account for the potential temporal variation and nonlinearities. Furthermore, the possible heteroscedasticity of the shocks and nonlinearities in the simultaneous relations among the variables of the model is captured by the multivariate stochastic volatility. Considering the fact that we are allowing for the time variation both in the coefficients and the variance-covariance matrix, hence, it is left up to the data to determine whether the time variation of the linear structure derives from changes in the size of the shocks (impulse) or from changes in the propagation mechanism (response) ${ }^{14}$. To start with, let's consider the following:

$$
y_{t}=C_{t}+B_{1, t} y_{t-1}+\ldots \ldots \ldots \ldots+B_{k, t-k}+u_{t} \quad \mathrm{t}=1, \ldots \ldots \ldots, \mathrm{T} . \quad \text { (1) }
$$

Where $y_{t}$ is an $\mathrm{n} \times 1$ vector of observed endogenous variables i.e. the real effective exchange rates, inflation rate, current account balance as $\%$ of GDP; $C_{t}$ is an $\mathrm{n} \times 1$ vector of time-varying coefficients that multiply constant terms; $B_{i, t, i=1, \ldots, k}$ are the $\mathrm{n} \times \mathrm{n}$ matrices of time-varying coefficients; $u_{t}$ are heteroscedastic unobservable shocks with variance-covariance matix $\Omega_{t}$ which is defined by

$$
A_{t} \Omega_{t} A_{t}^{\prime}=\sum_{t} \sum_{t}^{\prime}
$$

Where $A_{t}$ is the lower triangular matrix,

$$
A_{t}=\left[\begin{array}{cccc}
1 & 0 & \ldots & 0 \\
a_{10} & 1 & \ddots & \vdots \\
\vdots & \ddots & \ddots & 0 \\
a_{n 1, t} & \ldots & a_{n n-1, t} & 1
\end{array}\right]
$$

And $\sum_{t}$ is the diagonal matrix

$$
\sum_{t}=\left[\begin{array}{cccc}
\sigma_{1, t} & 0 & \ldots & 0 \\
0 & \sigma_{2, t} & \ddots & \vdots \\
\vdots & \ddots & \ddots & 0 \\
0 & \ldots & 0 & \sigma_{n, t}
\end{array}\right]
$$

Thus, it follows that

$$
y_{t}=C_{t}+B_{1, t} y_{t-1}+\ldots \ldots \ldots \ldots+B_{k, t-k}+A_{t}^{-1} \sum_{t} \varepsilon_{t}
$$

\footnotetext{
${ }^{13}$ See Primiceri (2005) for a detailed and interesting insight on the development of Time Varying Parameter SVAR framework. In order to conserve the space, we would be abstract on the discussion of TVP-SVAR model, however interested reader can refer to Primiceri (2005) or later who followed this approach, e.g. Nasir (2017).

${ }^{14}$ Note, the employed framework admits various kinds of shocks (Primiceri, 2005)
} 


$$
V\left(\varepsilon_{t}\right)=I_{n}
$$

If we stack up all the Right-hand Side coefficients in the Eq. (3) in a vector $B_{t}$ and rewrite it as;-

$$
\begin{array}{r}
y_{t}=X_{t}^{\prime} B_{t}+A_{t}^{-1} \sum_{t} \varepsilon_{t}, \\
X_{t}^{\prime}=I_{n} \otimes\left[1, y_{t-1}^{\prime}, \ldots, y_{t-k}^{\prime}\right]
\end{array}
$$

Whereas the Kronecker product is denoted by the symbol $\otimes$. For the true spirit of TVSVAR, the matrix $A_{t}$ should be time-variant. Simply letting the $A_{t}$ constant would imply that innovation to the $i-t h$ variable has a time-invariant effect on the $j-t h$ variable which would be obviously not desirable. Particularly, in a time-varying framework where the simultaneous interactions are of fundamental importance, as is the case of the subject treatise. Now if we let the $a_{t}$ to be the vector of non-zero and non-one elements of the matrix $A_{t}$ and $\sigma_{t}$ be the vector of the diagonal element s of the matrix $\sum_{t}$, the dynamics of time-varying parameter can be specified as follows:-

$$
\begin{aligned}
& B_{t}=B_{t-1}+v_{t}, \\
& a_{t}=a_{t-1}+\zeta_{t}, \\
& \log \sigma_{t}=\log \sigma_{t-1}+\eta_{t},
\end{aligned}
$$

Where the elements of the vector $B_{t}$ are modeled as the free elements of the matrix $A_{t}$ as well as random walks ${ }^{15}$. With the following assumptions on the variance-covariance matrix, all the innovations in the model are considered to be jointly normally distributed:

$$
V=\operatorname{Var}=\left(\left[\begin{array}{l}
\varepsilon_{t} \\
v_{t} \\
\zeta_{t} \\
\eta_{t}
\end{array}\right]\right)=\left[\begin{array}{cccc}
I_{n} & 0 & 0 & 0 \\
0 & Q & 0 & 0 \\
0 & 0 & S & 0 \\
0 & 0 & 0 & W
\end{array}\right]
$$

Where $I_{n}$ is an $\mathrm{n}$ x n-dimensional identity matrix $Q, S$ and $W$ are positive definite matrices ${ }^{16}$. In each equation, the coefficients of the contemporaneous relations are assumed to evolve independently. This increases the efficiency of the estimation algorithm.

\subsection{Bayesian Estimation \& Prior Selection}

The Bayesian approach is employed to estimate the model and for the evaluation of the posterior distribution of the parameters $\left(B^{T} A^{T} \Sigma^{T}\right)$ and hyperparameters of the variance-covariance matix $V$. We employed Gibbs Sampling for the posterior numerical evaluation of the parameters of interest. This approach delivers efficient estimates (Primiceri, 2005). In the selection of prior's distributions, we adhere to the principle of appropriateness and applicability. To begin, it is intuitive to assume that the initial states for the coefficients, covariances, log volatilities and the hyperparameters are independent of each other. The priors for the hyperparameters, $Q, W$ and the blocks of $\mathrm{S}$, are assumed to be distributed as independent inverse-Wishart. Furthermore, the priors for the initial states of the timevarying coefficients, simultaneous relations and log standard errors $p\left(B_{0}\right), p\left(a_{0}\right)$, and $p\left(\log _{\sigma 0}\right)$, are assumed to be normally distributed. These assumptions together with (eq. $5-7$ ) imply normal priors on the entire sequences of the B's, $\alpha$ 's and $\log \sigma$ 's (conditional on $\mathrm{Q}, \mathrm{W}$ and $\mathrm{S}$ ). The use of normal priors is fairly standard and as they are not conjugate hence brings the benefit of tractability (Sims and Zha,

\footnotetext{
${ }^{15}$ Classed as stochastic volatility, $\sigma_{t}$ are assumed to evolve as geometric random walks (Shepherd, 1996).

${ }^{16}$ Primiceri (2005).
} 
1998; Smith and Kohn, 2002; Primiceri, 2005). In order to generate a sample from the joint posterior of $B^{T} A^{T} \Sigma^{T}$ and $V$, The MCMC algorithm is employed. To exploit the blocking structure of the unknowns, the Gibbs sampling is employed which entails four steps, i) drawing in turn time-varying coefficients $B^{T}$, ii) simultaneous relations $A^{T}$, iii) volatilities $\Sigma^{T}$ and iv) hyperparameters $V$, conditional on the observed data and the rest of the parameters ${ }^{17}$. We employ this empirical framework on data from the three first movers of inflation targeting countries (New Zealand, UK and Canada).

\subsection{Dataset}

Our dataset entails times series on the real effective exchange rate (REER), inflation and trade balance of respective countries. In order to gain a deeper and comprehensive insight into the ERPT over a broader time horizon, we endeavoured to use the longest possible time series for each country. Specifically, we tried to encompass the period before the start of inflation targeting. The data was collected from Thomson Reuter's database. The details of the data on each of the variable for the three countries are as follows:

Inflation: For the inflation in the UK, we used the monthly data on Real Price Index (excluding the mortgage/interest payments) as a proxy. One choice could have been the Consumer Price Index; however, the data on CPI was available only from 1989 and hence there was a very limited sample before the start of inflation targeting by the Bank of England. Secondly, the RPI is also very inclusive index and does not include the mortgage payments which is a very intuitive exclusion if we are looking at the impact of ERPT. We collected the data on RPI (Excluding mortgage/interest payments) from January 1976 to December 2017. For Canada, to proxy inflation, we used the monthly data on the annual Consumer Price Index (standardised and seasonally adjusted). Lastly, for New Zealand the monthly data on the consumer price indexed, the data was standardized and seasonally adjusted.

Real Effective Exchange Rate: We used the Real Effective Exchange Rate as a proxy for the exchange rate for all the countries. For the United Kingdom, Canada and New Zealand we collected data on Bank of International Settlements (BIS) monthly Real Narrow Effective Exchange Rate Index. The REER is calculated as geometric weighted averages of bilateral exchange rates and the weighing pattern are time-varying which is important to account for the importance of counterparts in international trade and exchange rates. The data was available from October 1963 to December 2017.

Trade Balance: For the trade balance, we used the current account balance as a percentage of GDP, standardized (seasonally adjusted). There were quarterly observations available from 1960q1 to 2017q3 for the UK, whereas for Canada data was available from the $1^{\text {st }}$ quarter of 1981. For New Zealand, the data was available from the $2^{\text {nd }}$ quarter of 1987 . We used the linear interpolation to convert the quarterly series into monthly and to match the frequency with the other variables frequencies.

\subsection{Analysis and Findings}

To start with, we performed the stationarity test to gain insight into the characteristics of the underlying data series. For this purpose, we performed the ADF Unit Root test with a structural break in the data series. In terms of the date of the structural break, we let it be determined endogenously by using the underlying data series rather than giving an exogenous or discretionary date. Hence, the date of the structural break was chosen based on the strongest evidence of the break. Specifically, to allow for evaluation of one-sided alternatives, alternative maximise and minimize options are provided. This produces different critical values for the final DF test statistic and as compare to the non-directional alternatives, possess greater power ${ }^{18}$. The ADF test is applied to test for the unit root in the presence of

\footnotetext{
${ }^{17}$ See Primiceri (2005) for further details on structural interpretation and identification.

18 Studies for instance, Banerjee et al., (1992), Zivot and Andrews (1992) and Vogelsang and Perron (1998) supported this practise.
} 
break with both Innovative Outliers (IO) and Additive Outliers (AO) as classified Fox (1972) and Tsay (1988). The optimal lag length selection is based on the Schwarz Information Criteria (SIC) which is appropriate with the large samples and particularly in the presence of structural break (Ashgar and Abid 2007). The results are presented in Table 1 as follows;

Table 1: ADF Unit Root Test with Structural Break: Additive \& Innovative Outliers

\begin{tabular}{|c|c|c|c|c|c|}
\hline \multirow{13}{*}{ Level } & Variables & $\begin{array}{c}\text { ADF Test } \\
\text { Statistic (IO) } \\
\end{array}$ & P-Values & $\begin{array}{c}\text { ADF Test Statistic } \\
(A O)\end{array}$ & P-Values \\
\hline & United Kingdom & & & & \\
\hline & REEER & -4.299 & 0.337 & -4.480 & 0.245 \\
\hline & Inflation & $-5.964 *$ & $<0.01$ & $-5.428 * *$ & 0.025 \\
\hline & Trade Balance & -4.291 & 0.342 & -4314 & 0.329 \\
\hline & Canada & & & & \\
\hline & REER & -3.294 & 0.896 & -3.260 & 0.907 \\
\hline & Inflation & -4.958 & 0.080 & -5.011 & 0.076 \\
\hline & Trade Balance & -4.207 & 0.389 & -4.528 & 0.224 \\
\hline & New Zealand & & & & \\
\hline & REER & -3.479 & 0.822 & -3.484 & 0.820 \\
\hline & Inflation & $-6.476^{*}$ & $<0.01$ & $-6.551 *$ & $<0.01$ \\
\hline & Trade Balance & -4.991 & 0.079 & $-5.210 * *$ & 0.04 \\
\hline \multirow[t]{12}{*}{ 1st Difference } & United Kingdom & & & & \\
\hline & REER & $-17.469 *$ & $<0.01$ & $-17.768 *$ & $<0.01$ \\
\hline & Inflation & $-18.985^{*}$ & $<0.01$ & $-19.136^{*}$ & $<0.01$ \\
\hline & Trade Balance & $-6.277 *$ & $<0.01$ & $-8.239 *$ & $<0.01$ \\
\hline & Canada & & & & \\
\hline & REER & $-17.286^{*}$ & $<0.01$ & $-17.324 *$ & $<0.01$ \\
\hline & Inflation & $-10.269 *$ & $<0.01$ & $-20.242 *$ & $<0.01$ \\
\hline & Trade Balance & $-7.773 *$ & $<0.01$ & $-9.211 *$ & $<0.01$ \\
\hline & New Zealand & & & & \\
\hline & REER & $-16.007 *$ & $<0.01$ & $-16.409 *$ & $<0.01$ \\
\hline & Inflation & $-17.461 *$ & $<0.01$ & $-18.127 *$ & $<0.01$ \\
\hline & Trade Balance & $-6.215^{*}$ & $<0.01$ & $-9.557 *$ & $<0.01$ \\
\hline
\end{tabular}

$* 1 \%$ level of significance $* * 5 \%$ level of significance $* * *$ Vogelsang (1993) asymptotic one-sided p-values.

The results of the ADF unit root test suggested that for most the series the null of no unit root could not be rejected at a statistical level of significance ( $1 \%$ \& 5\% levels). However, at the first difference, all the serious were found to be stationary i.e. I (1). This is a quite common feature of economic and financial time series and does not suggest explosive behaviour. In order to gain some further insight into the inflation dynamics, we are also reporting on the graphs of Dickey-Fuller t-stats and the DickeyFuller Autoregressive coefficients for the series on the inflation. The graphs are based on the ADF unit root test (summarised in Table 1) and are presented for each country as follows; -

\section{United Kingdom}



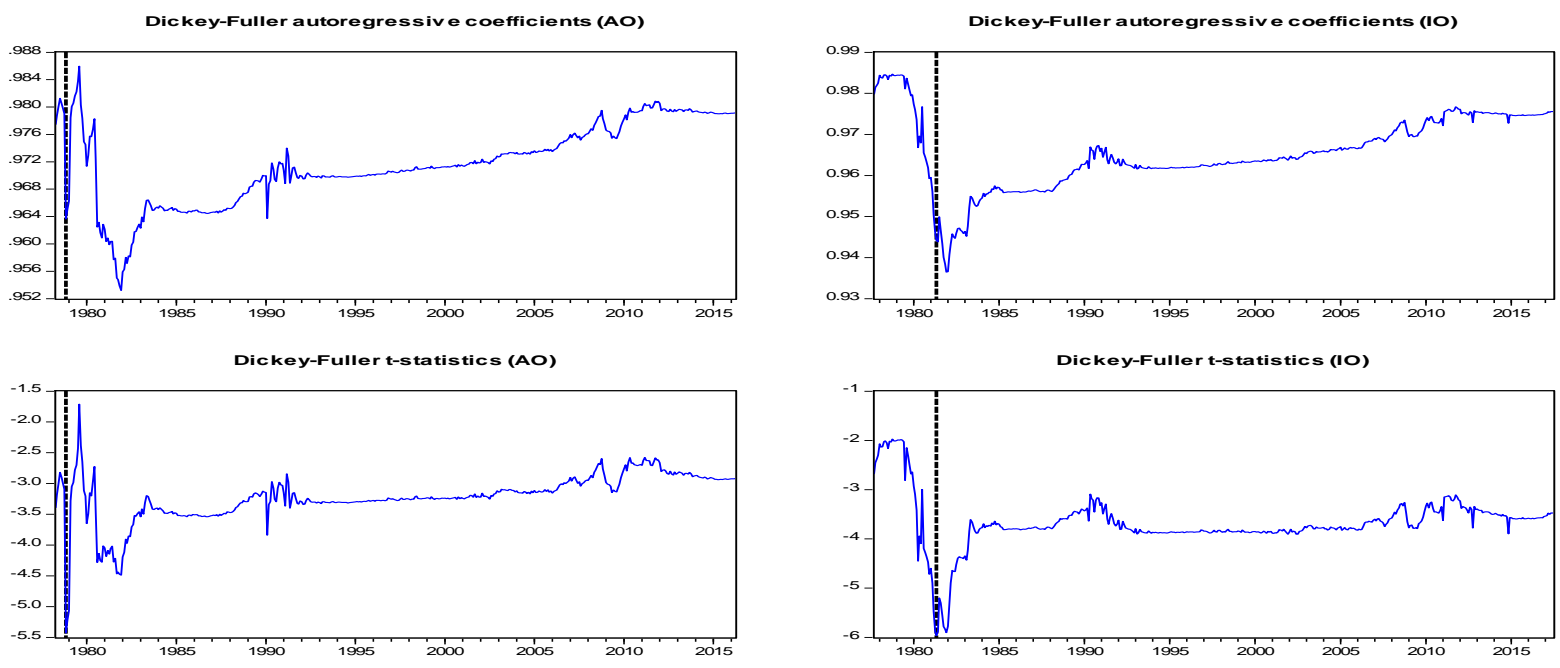

\section{Canada}
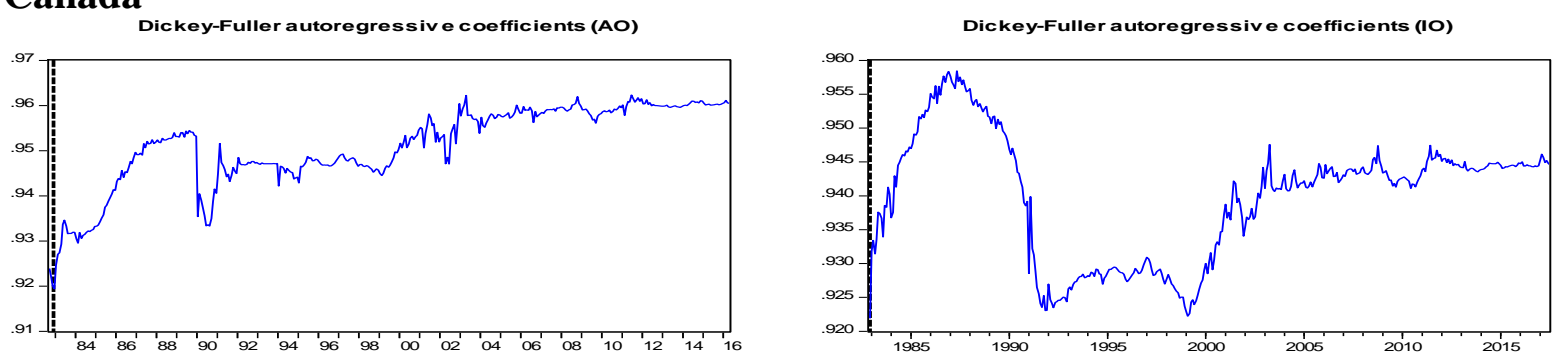

Dickey-Fuller t-statistics (AO)
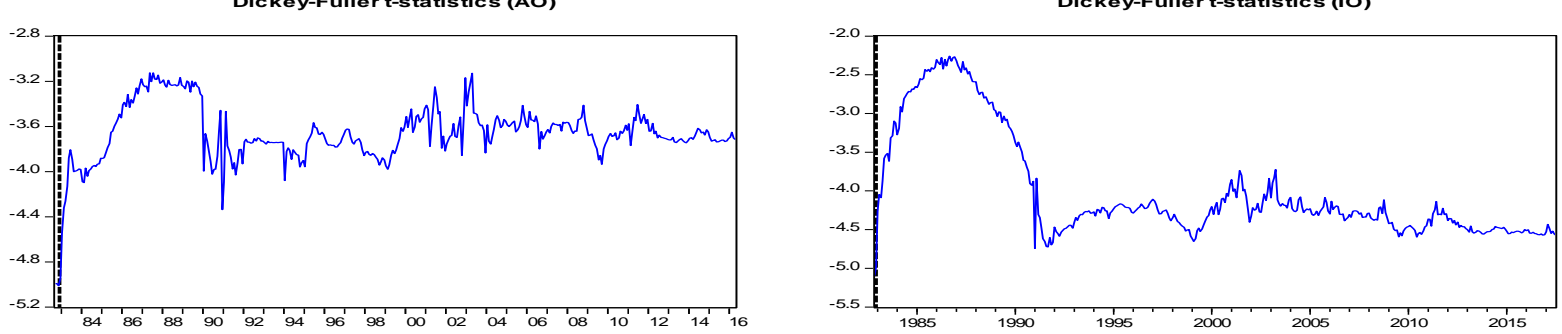

\section{New Zealand}
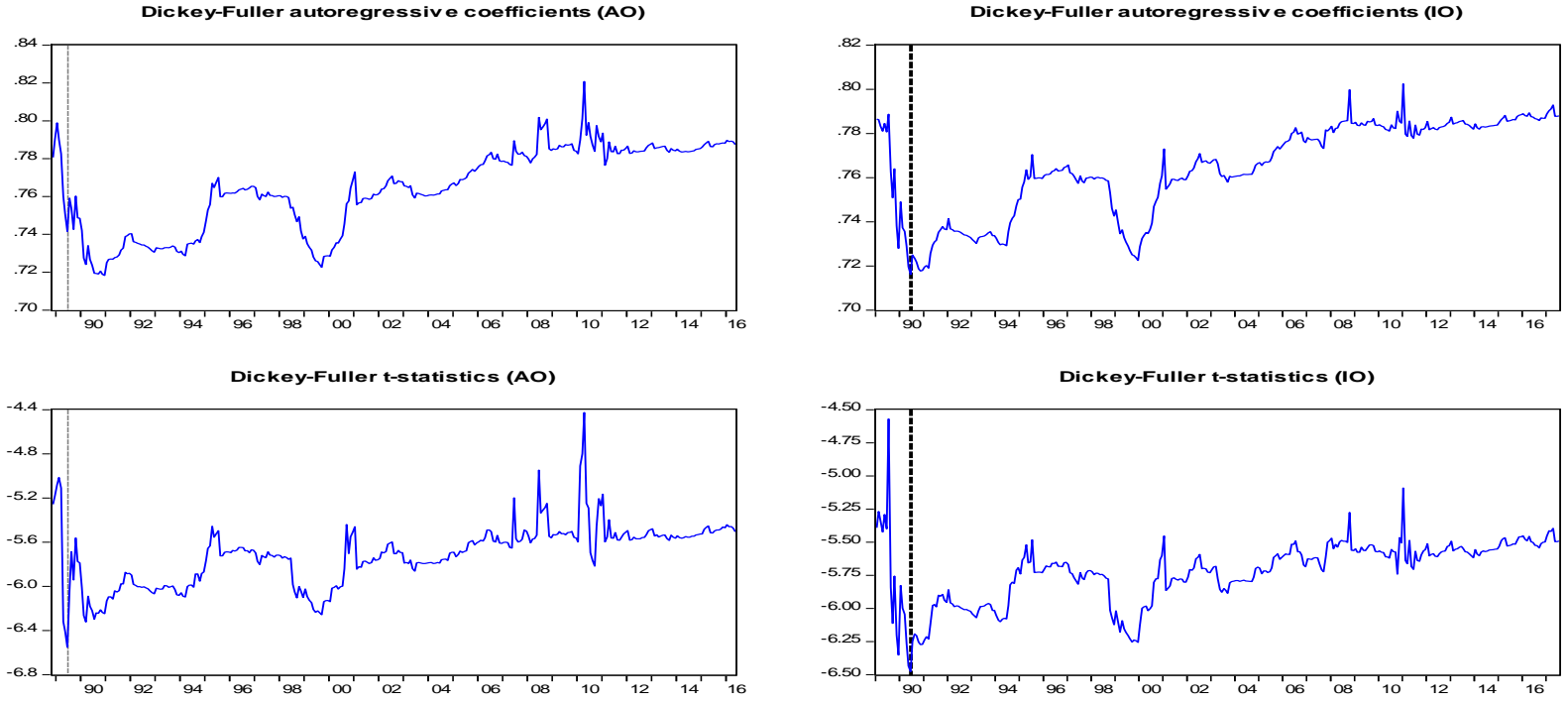

Figure 4: Dickey-Fuller t-stats and the Dickey-Fuller Autoregressive coefficients for Inflation using Additive and innovation outliers. 
The results of the Dickey-Fuller t-stats and the Dickey-Fuller Autoregressive coefficients for inflation using the Additive and Innovation outliers presented in Figure 4 suggest signs of structural breaks and major oscillations in the series for inflation. For the UK, it showed a structural break around the early 1980s which was the largest and sharpest. Interesting, around the period of the start of inflation targeting (1992) as well as great moderation, there was some volatility and oscillation which was succeeded by a period of tranquillity (great moderation) till some upheaval around the GFC. For Canada, the strongest structural break was found in the early 1980s. Nonetheless, there was also some oscillation in coefficient around the period corresponded to start of inflation targeting, however, since then there was a period of tranquillity. In this regard, our findings are in line with the Beaudry and Ruge-Murcia (2017) analysis on Canada. For New Zealand our period of analysis started from June 1987, hence the period of the great inflation of the 1980s was not fully encompassed. However, it showed that the strongest structural break corresponded to the start of inflation targeting, since then there had been some periods of oscillations around the early 2000s and GFC, but inflation remained comparatively modest. In terms of drawing an overarching inference for the behaviour of inflation in the underlying economies, one may argue that the inflation targeting might have played a part, though such an inference requires to be considered with a pinch salt. This is due to the fact that the inflation targeting began with the start of the period of price and output stability i.e. the Great Moderation. The great moderation ended with the great recession and the GFC, through inflation targeting is still going on which implies that the role of inflation targeting in taming the inflation shall be seen in a broader context. The next question is on the role of inflation targeting in ERPT. We will look into that by employing a TVSVAR framework.

\subsection{TVSVAR Model}

\subsection{United Kingdom}

We started our analysis with the UK. In terms of ordering of variables, considering the exogenous nature of the Real Effective Exchange Rate we ordered them last. Nonetheless, the identification assumption implies that the exchange rate shocks affect with lags. The simultaneous interaction between exchange rate, inflation and trade balance is arbitrarily modelled in a lower triangular form with the Inflation (RPI) coming first. This was for the sake of normalisation and not an identification condition, although it is very intuitive to expect that the price levels may respond quicker than trade balance, as the adjustment to the latter would be a response to the former. The logic of this argument is embedded in the Hume's (1742) price-specie flow mechanism. However, to satisfy the curiosity, we ensured that in this setting the ordering of the exchange rate block does not affect the empirical results. We performed 10000 iterations of the Gibbs Sampling with a total burn rate of $20 \%$ (2000 iterations). For the training sample, the first 60 observations (five years) were chosen. Figure 4 presents the time-varying standard deviation of the exchange rate shocks. It entails the $16^{\text {th }}$ and $84^{\text {th }}$ percentiles (corresponding to one standard deviation confidence interval) of the time-varying standard deviation of the shocks and plot of the posterior mean. 

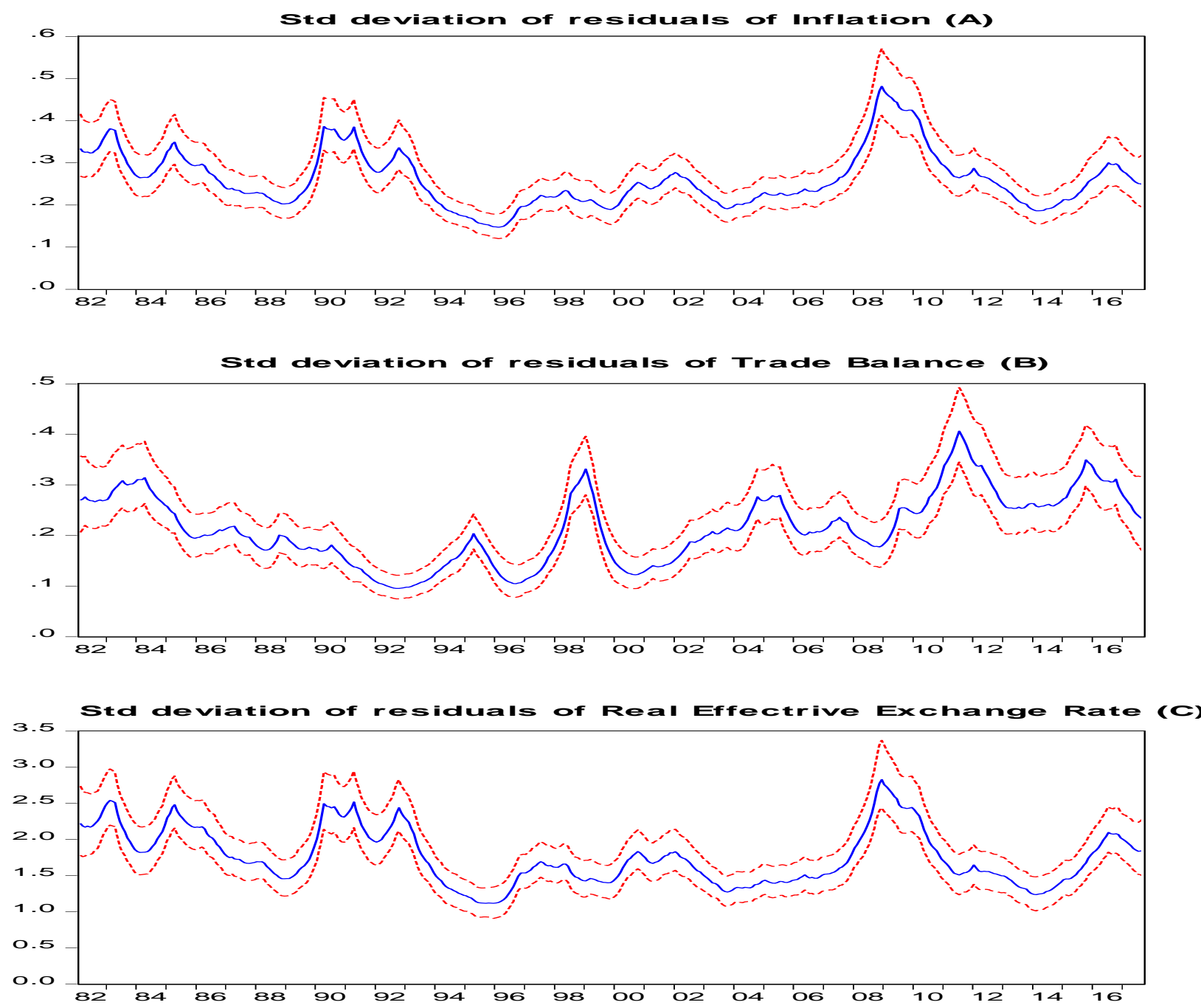

Figure 5: Posterior mean, 16 $^{\text {th }}$ and 84-th percentiles of the standard deviation of $(\mathrm{A})$ residual of the Inflation Rate (B) residual of the Trade Balance (\% of GDP) and (C) residuals of the equation for Real Effective Exchange Rate (REER) Shock for the United Kingdom.

The Figure 5 (A to C) provides a clear indication on the inflation as round the period of the UK starting Inflation Targeting, Exchange Rate Mechanism (ERM) saga and events leading to Black Wednesday (1992), the inflation has been very volatile. However, since then there has been a period of persistent tranquillity lasted until the dawn of GFC. There was again a surge in volatility around Brexit. The balance of trade has been persistently volatile, though the period post-GFC seemed to be more volatile which is understandable if we look at the events and uncertainty surrounding the international trade since GFC. Interestingly the exchange volatility was even more pronounced as clearly witness high oscillations around ERM, GFC and most recently around Brexit referendum (Nasir and Morgan, 2018).

We start to analyse the ERPT from its impact on Inflation. The results of exchange rate shocks and the response of inflation are summarised in Figure $6(\mathrm{~A}-\mathrm{E})$. 

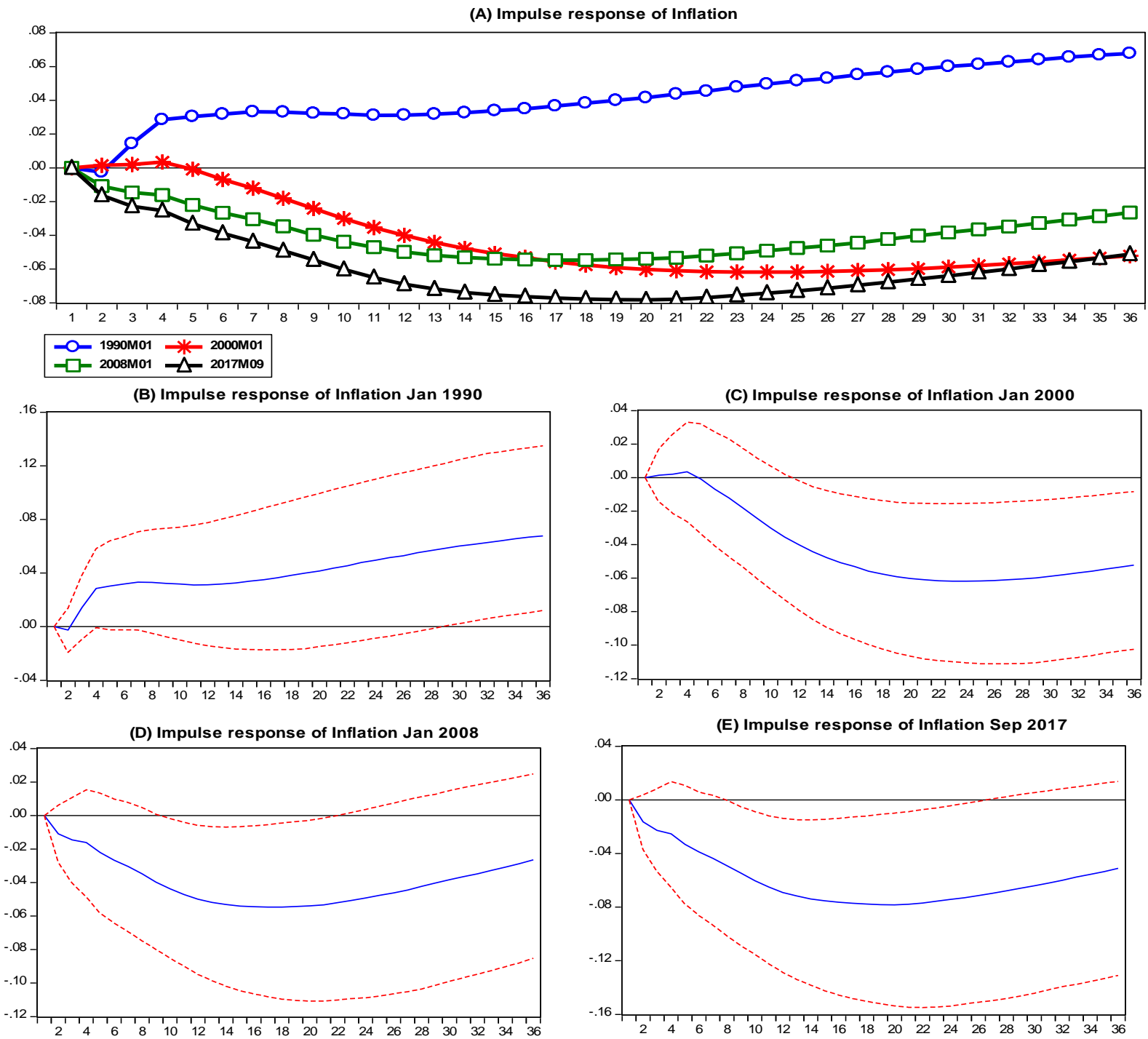

Figure 6: Response of Inflation to Exchange Rate Shocks, Jan 1990, 2000, 2008 \& September 2017(6A). Pairwise differences between the responses in corresponding periods with $16^{\text {th }}$ and $84^{\text {th }}$ percentiles $(6 \mathrm{~B}-\mathrm{E})$.

As presented in Figure 6, we choose four different dates to analyse and compare the ERPT to inflation in the UK. The pairwise differences between the impulse responses in different dates with the 16-th and 84-th percentiles are also presented. Chosen dates are January 1990, January 2000, January 2008 and September 2017. The choice of dates is due to the corresponding macro-financial events and environment of prevailing periods, specifically, the January 1990 was chosen as a date before the start of inflation targeting in the UK. The January 2000 was chosen as the start of the millennium and postindependence of the Bank of England, the January 2008 is chosen as the date before the GFC ${ }^{19}$ events including monetary policy hitting the ZLB. Lastly, the September 2017 was selected as the latest date of data available by the writing of this paper. The results suggest significant evidence of ERPT. However, there is clear evidence that the magnitude, as well as the direction was time-variant. It showed that the positive REER shock which implies an appreciation of the Sterling led to a positive effect on inflation before the BoE starting inflation targeting (January 1990). Interestingly, in the periods after the adoption of inflation targeting and independence of the BoE, there is a clear indication that the positive exchange rate shocks led to a significant drop in inflation. It implied that the inflation targeting

19 Just before Northern-Rock, secured help from the British Government to over-come liquidity crises. 
and the Bank of England's independence have in fact come with an increase in the ERPT to inflation rather a decrease. In the latest period, where the monetary policy was at ZLB, the impact of ERPT was highest in magnitude. Our findings add to the understanding of ERPT to inflation and provide an alternative perspective to the argument by Pourroy (2012) that a managed exchange rate environment delivers a stronger nominal anchor to inflation shock and concomitantly helps in inflation targeting. In fact, what is evident is that in specific to the UK, where we have a floating regime with a statutory inflation target, ERPT has implications for price stability. The results are contrary to Calvo and Reinhart (2000) argument that ERPT is only large for the emerging markets as compared to developed countries. In specific to the Inflation Targeting, our results contradict the notion by Gagnon and Ihrig (2004), Junior (2007) and Edwards (2007) that the countries that have adopted inflation targeting may lead to a decline in the pass-through from exchange rate changes to inflation. The evidence suggests that a Quarter-Century of inflation targeting in the UK may have been successful in taming inflation, however, the ERPT to inflation holds its grounds fairly strongly. Lastly, results also suggested that ERPT has shown the highest impact in the latest period. These findings support the notion by Forbes (2016 and 2017) and Nasir and Simpson (2018) that if anything, ERPT has increased over time. After inflation, we report on the ERPT to the trade balance. The results are presented in Figure 7.

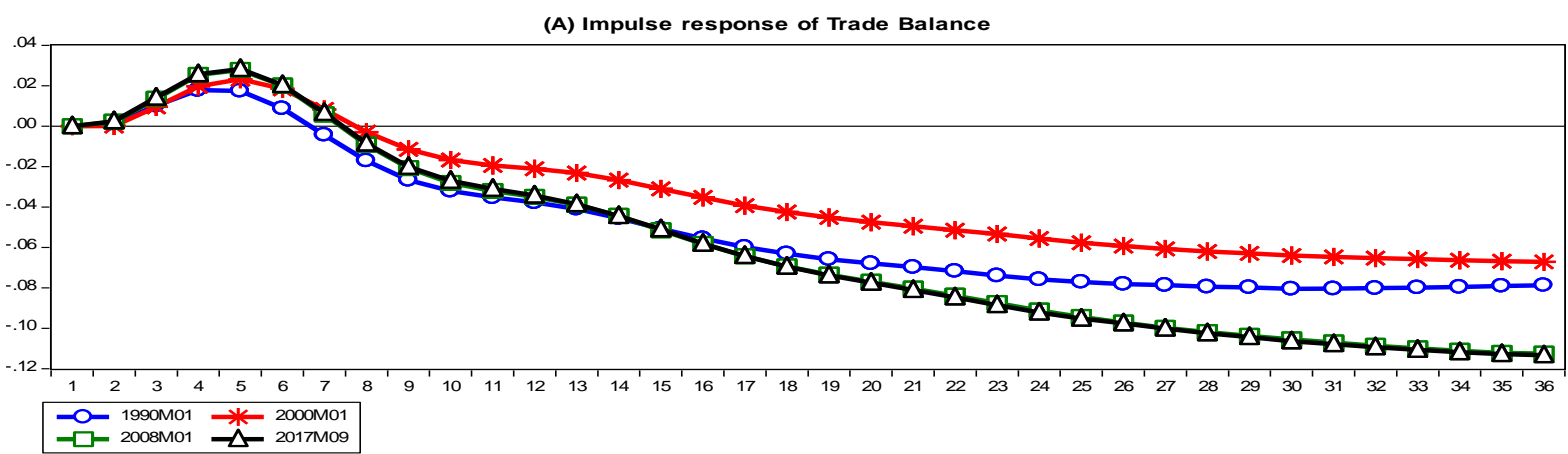

(B) Impulse response of Trade Balance Jan 1990

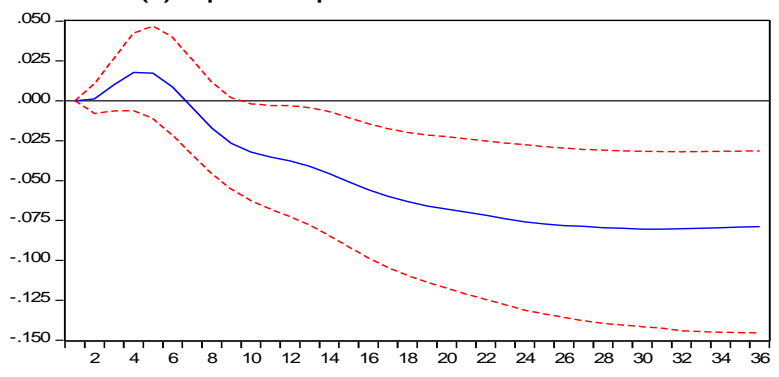

(D) Impulse response of Trade Balance Jan 2008

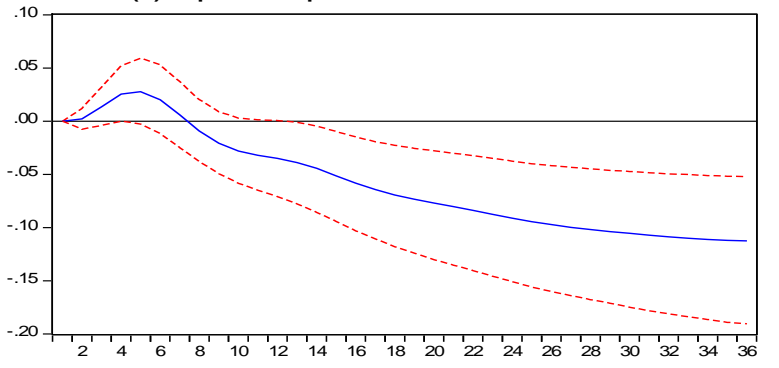

(C) Impulse response of Trade Balance Jan 2000

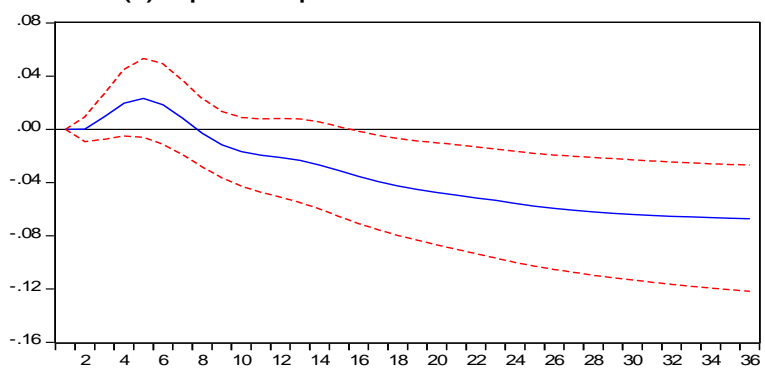

(E) Impulse response of Trade Balance September 2017

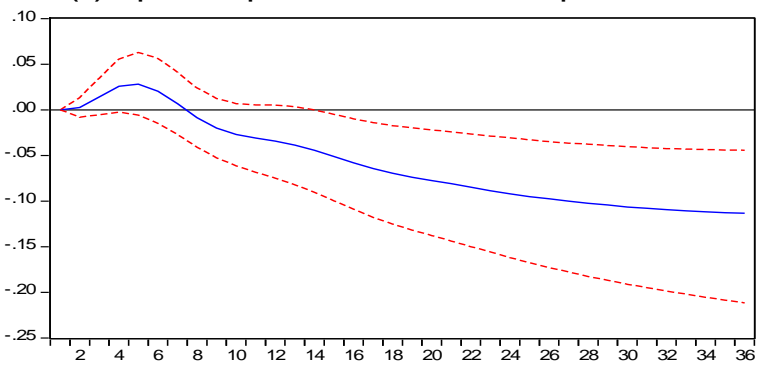

Figure 7: Response of UK Trade Balance to Exchange Rate Shocks, Jan 1990, 2000, 2008 \& September 2017(7A). Pairwise difference between the responses in corresponding periods with $16^{\text {th }}$ and $84^{\text {th }}$ percentiles (7B-E).

The results on the ERPT to UK trade balance showed that a positive shock to the real effective exchange rate (appreciation) leads to an initial modest improvement and thereafter a persistent worsening of the 
trade balance in the UK. This was a prima facie manifestation of a $J$-curve behaviour ${ }^{20}$ (though in the opposite direction due to positive shocks). It also implies that the depreciation of Sterling could bring international competitiveness for the UK's economy and its external balance. The findings are in line with the existing evidence on the presence of J-Curve and response of trade balance to exchange rate dynamics, for instance, study on USA and Indonesia by Bahmani-Oskooee and Harvey (2015) and among others, Bahmani-Oskooee and Hegerty (2010) and Bahmani-Oskooee et al., (2013), Yildirim and Ivrendi (2016). However, the results are contrary to the studies which could not find evidence of a significant impact of exchange rate on the trade balance. For instance, study by Aristotelous (2001) which was limited to the UK-US bilateral trade and Rose and Yellen (1989) on the US data and Rose (1991) analysis of the five OECD countries (Canada, Germany, Japan, UK and US) based on the PostBreton Woods period (1974 - 86). Our results and employed novel framework which account for the time-variation suggests that the ERPT has important implications for the trade balance which could be associated with the increased structural changes, integration and openness of the economies. In this aspect and in specific to the UK, our findings complement the studies by Bahmani-Oskooee and Kovyryalova (2008) and Pattichis (2012) which were focusing on the UK's bilateral trade with US and study Bahmani-Oskooee (2016) bilateral trade between UK and its major trading partners (Canada, Germany, Japan, Italy, Norway, Korea, Spain and US). Furthermore, if we compare the Pre-inflation targeting period with the current period it suggests that there are subtle differences suggesting that the relationship has grown stronger. Although, it will not be wise to draw any strong inference on this subtle shift if we associate it with the inflation targeting, yet, it is prima facie evident that the ERPT to the trade balance under inflation targeting has not diminished and if anything, it has increased.

\subsection{Canada}

After the UK, we analysed the impact of ERPT on inflation and Canadian Trade balance. The ordering of the variables remained the same as in the case of the UK and for the same reasons. Similarly, we chose to perform 10000 iterations of the Gibbs Sampling with a burn rate of 20\% and first 60 observations (five years) were chosen for the training sample. However, this time the data available on the trade balance led us to limit time-horizon from March 1981 to September 2017. Spanning over an approximate period of 37 years and covering a decade before the dawn of inflation targeting broke on the Canadian soil. Hence, it was still the significant length of the period of the time to perform the longitudinal analysis converging Pre and Post inflation targeting regimes. We start with the presentation of the time-varying standard deviations of the REER shocks which are reported in Figure 8.

20 The notion of the "J-curve" suggests that following a currency depreciation, initially, the trade balance deteriorates before brining longer-term positive effects, hence forming a " $\mathrm{J}$ " shape ( Bahmani-Oskooee and Ratha, 2004). 

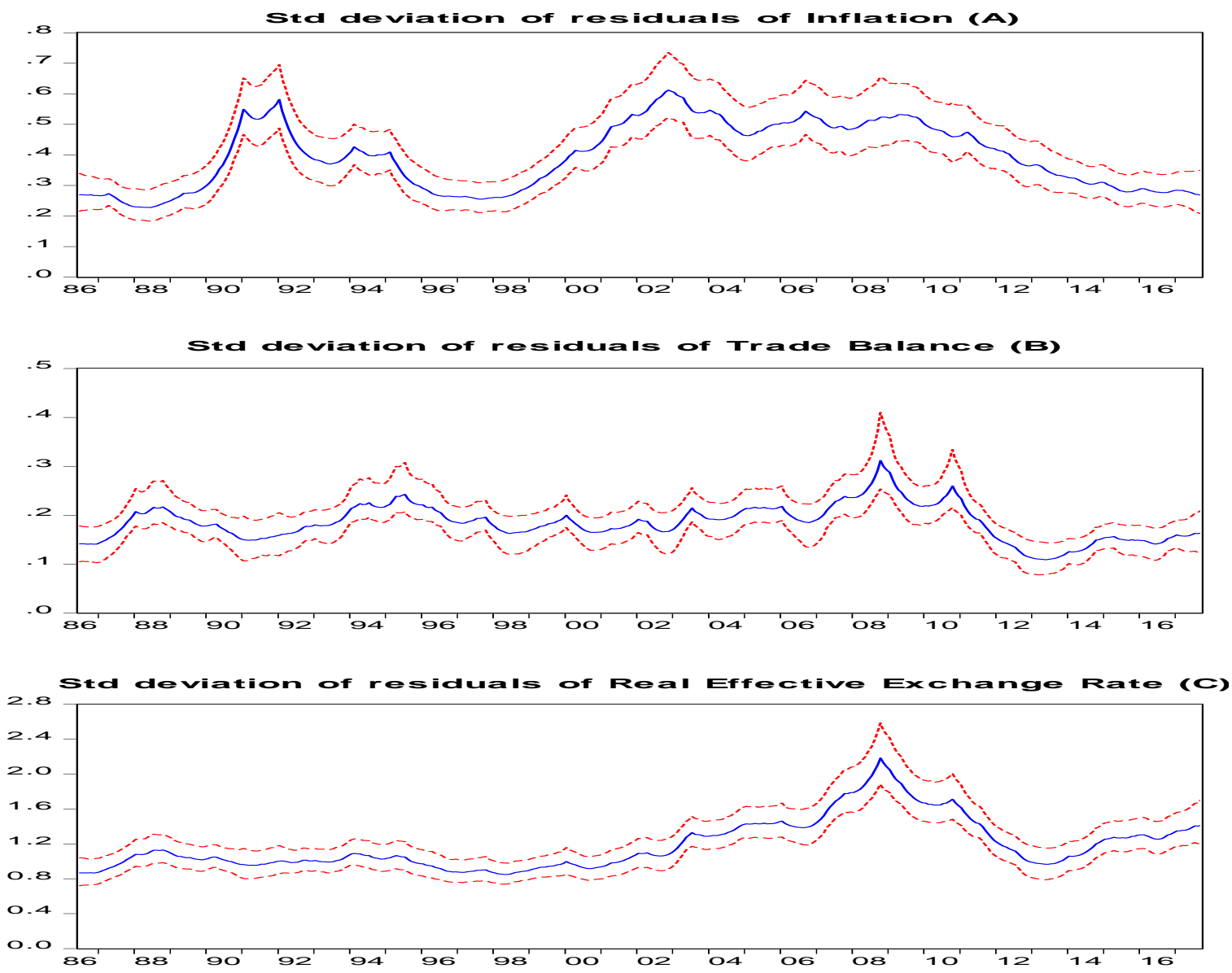

Figure 8: Posterior mean, $16^{\text {th }}$ and $84^{\text {th }}$ percentiles of the standard deviation of $(A)$ residual of the Inflation Rate (B) residual of the Trade Balance (\% of GDP) and (C) residuals of the equation for REER Shock for Canada.

Figure 8 (A-C) and the results on the posterior mean of the standard deviation of residuals of all the series show some interesting dynamics. It shows that in the run-up to Canada adopting the inflation targeting in the early 1990s. Since then the volatility in inflation has been mild till the start of the millennium. In the Post-GFC volatility of the inflation has been low which is intuitive and prima facie evident in the low inflation regime that follows the global crises. The trade balance and exchange rate showed consistent mild and consistent oscillation of residuals, however, the episode of GFC there has been an increase in the volatility which is once again intuitive considering the GFC as a major influencing factor in the international trade and exchange rate markets. Next, we analysed the ERPT to inflation, the results of the real effective exchange rate shocks and the response of inflation are summarised in Figure $9(\mathrm{~A}-\mathrm{E})$. 


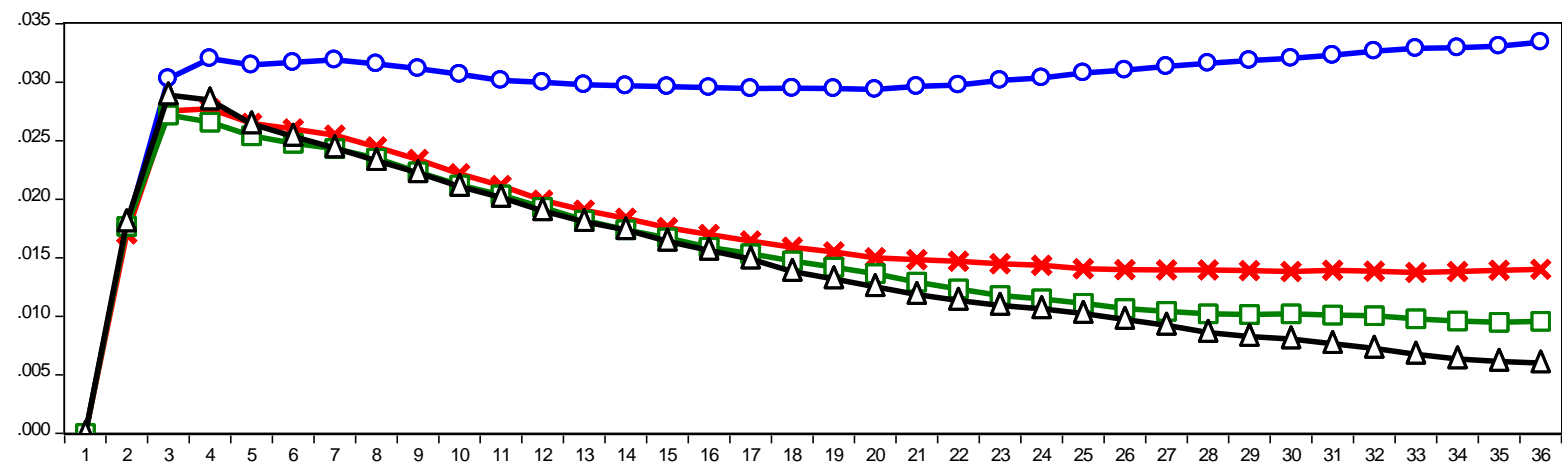

\section{-0 - 1991M01 $\because-2000 \mathrm{M} 01$
$-\square-2008 \mathrm{M} 01$
$-\triangle-2017 \mathrm{M} 09$}

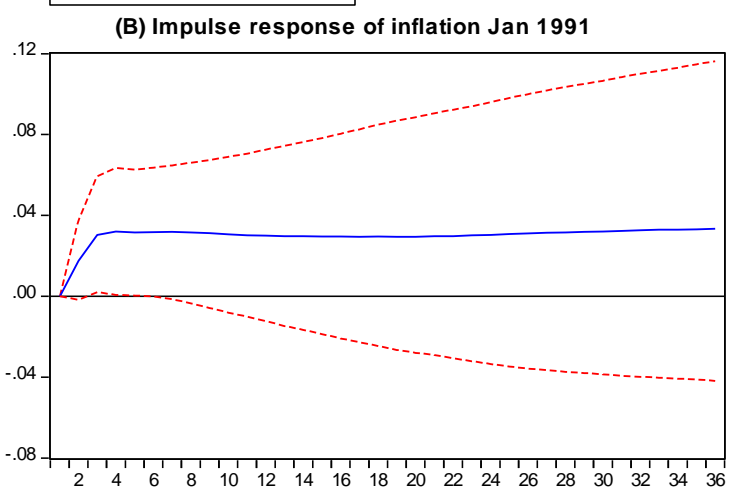

(D) Impulse response of inflation $2008 \mathrm{~m} 01$

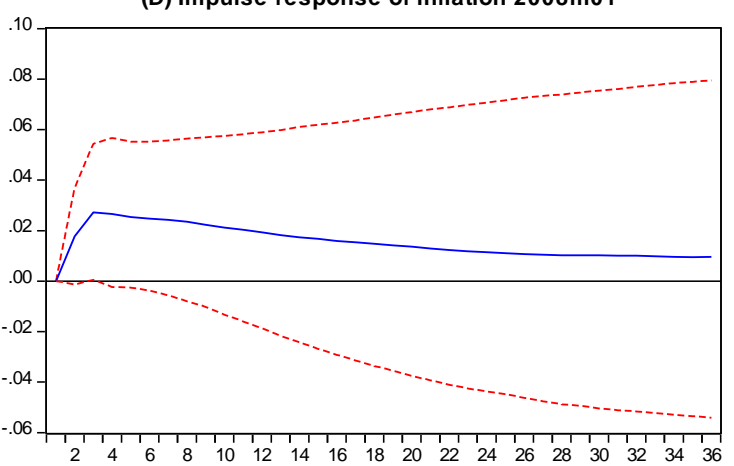

(C) Impulse response of inflation Jan 2000

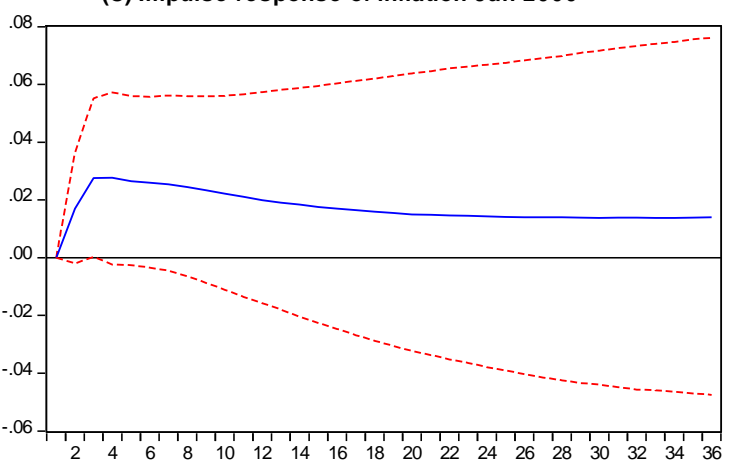

(E) Impulse response of inflation Sep 2017

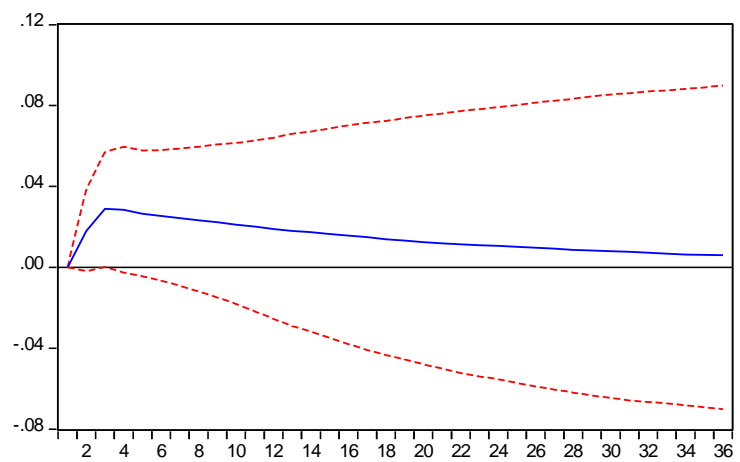

Figure 9: Response of Inflation to Exchange Rate Shocks, Jan 1991, 2000, 2008 \& September 2017(9A). Pairwise difference between the responses in corresponding periods with $16^{\text {th }}$ and $84^{\text {th }}$ percentiles (9B-E).

Four different dates were chosen to analyse and compare the ERPT to inflation and trade balance in Canada. These are January 1991, January 2000, January 2008 and September 2017. The pairwise difference between impulse responses in different dates with the $16^{\text {th }}$ and $84^{\text {th }}$ percentiles are also presented. The reason we chose January 1991 was to allow for sufficient space for the Pre-inflation targeting period and also for the training sample. The results showed that contrary to the UK, a positive shock to the REER led to an increase in inflation in Canada in all of the under-analysis periods. This implies that the appreciation of the currency in Canada puts upward pressure on inflation. Interestingly we see a significant element of time variation. In the Pre-Inflation targeting regime, the shock to inflation was more persistent and did not fade quickly. However, the results of the later periods suggested that despite the initial impact of a similar magnitude, the inflation rate returned to its equilibrium value rather swiftly. It could be associated with the ability of the inflation targeting regime which led to prompt adjustment rather than otherwise. After inflation, we report on the ERPT to Canadian trade balance and the results are presented in Figure 10 (A- E);- 


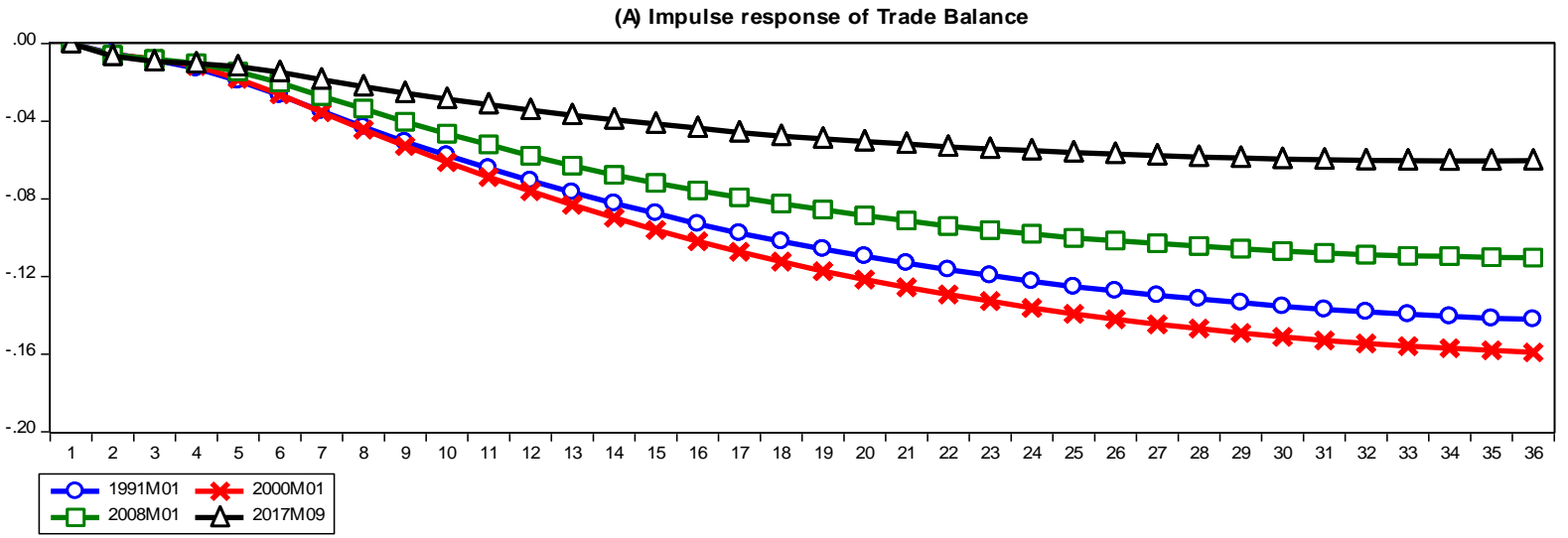

(B) Impulse response of Trade Balance Jan 1991

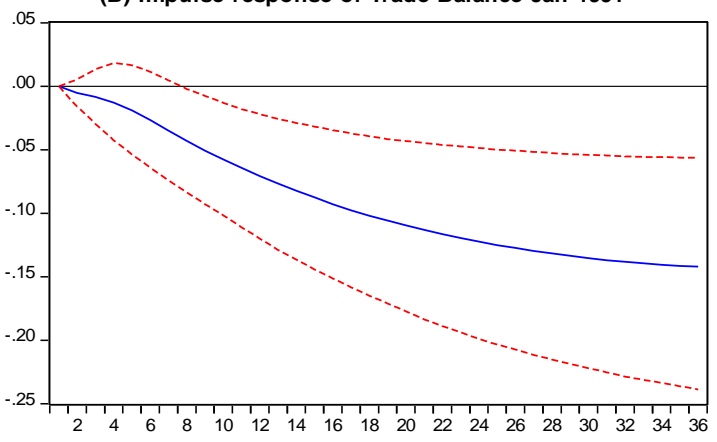

(D) Impulse response of Trade Balance Jan 2008

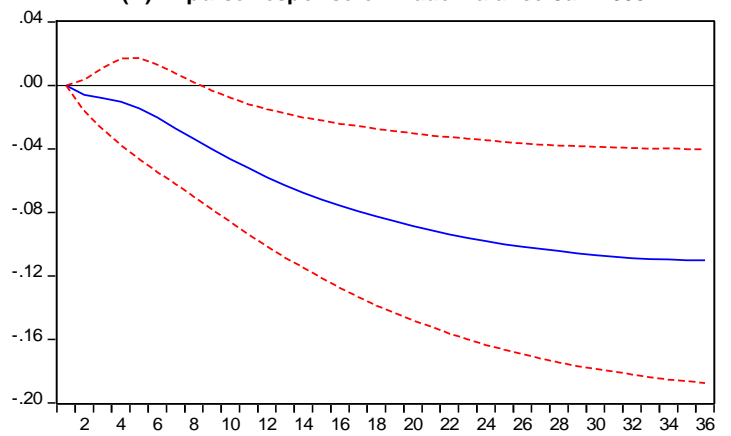

(C) Impulse response of Trade Balance Jan 2000

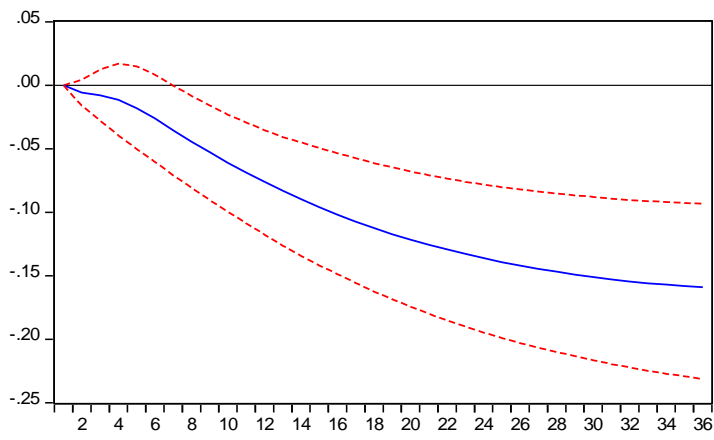

(E) Impulse response of Trade Balance Sep 2017

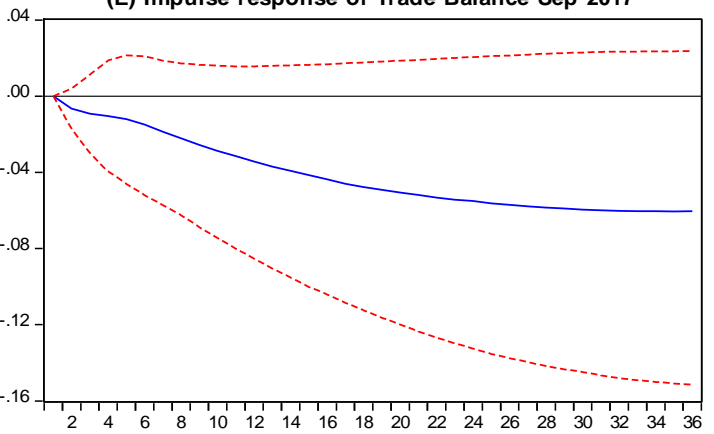

Figure 10: Response of Canadian Trade Balance to Exchange Rate Shocks, Jan 1991, 2000, 2008 \& September 2017(A). Pairwise difference between the responses in corresponding periods with $16^{\text {th }}$ and $84^{\text {th }}$ percentiles (10B-E).

The results on the Trade balance showed that the positive shocks to the REER led to the deterioration of trade balance in all the periods. There was a very subtle improvement in the trade balance at the beginning suggested by a blip in the impulse, however, it was not quite like a J-curve. The comparison of the ERPT in different periods suggests some difference, specifically, in the later parts it suggests that the ERPT to the trade balance decreased, though still remained significant.

\subsection{New Zealand}

Lastly, we analysed the ERPT to the inflation and Trade balance in New Zealand. Our period of the analysis is from June 1987 to September 2017. We put our best effort to go beyond June 1987 in our collection of data and in this endeavour the Stats New Zealand was contacted, however, it turned out there was no quarterly data published on the current balance to GDP before 1987. Therefore, we started our analysis from June 1987. Keeping the structure and layout of the model the same as we discussed in the case of UK, we performed 10000 iterations of the Gibbs Sampling with a burn rate of $20 \%$ and first 36 observations (three years) were chosen for the training sample. This was due to the reason that we wanted to draw the first impulse response analysis if not before, as soon as after New Zealand started 
inflation targeting. Although by comparison with Canada and UK the time horizon for New Zealand was shorter, it was still spanning over an approximate period of 30 years and covering a few years before New Zealand pioneered the inflation targeting. Hence, it is a significant length of the period of time to perform the longitudinal analysis. We start with the presentation of the time-varying standard deviation of the exchange rate shocks which are reported in Figure 10.
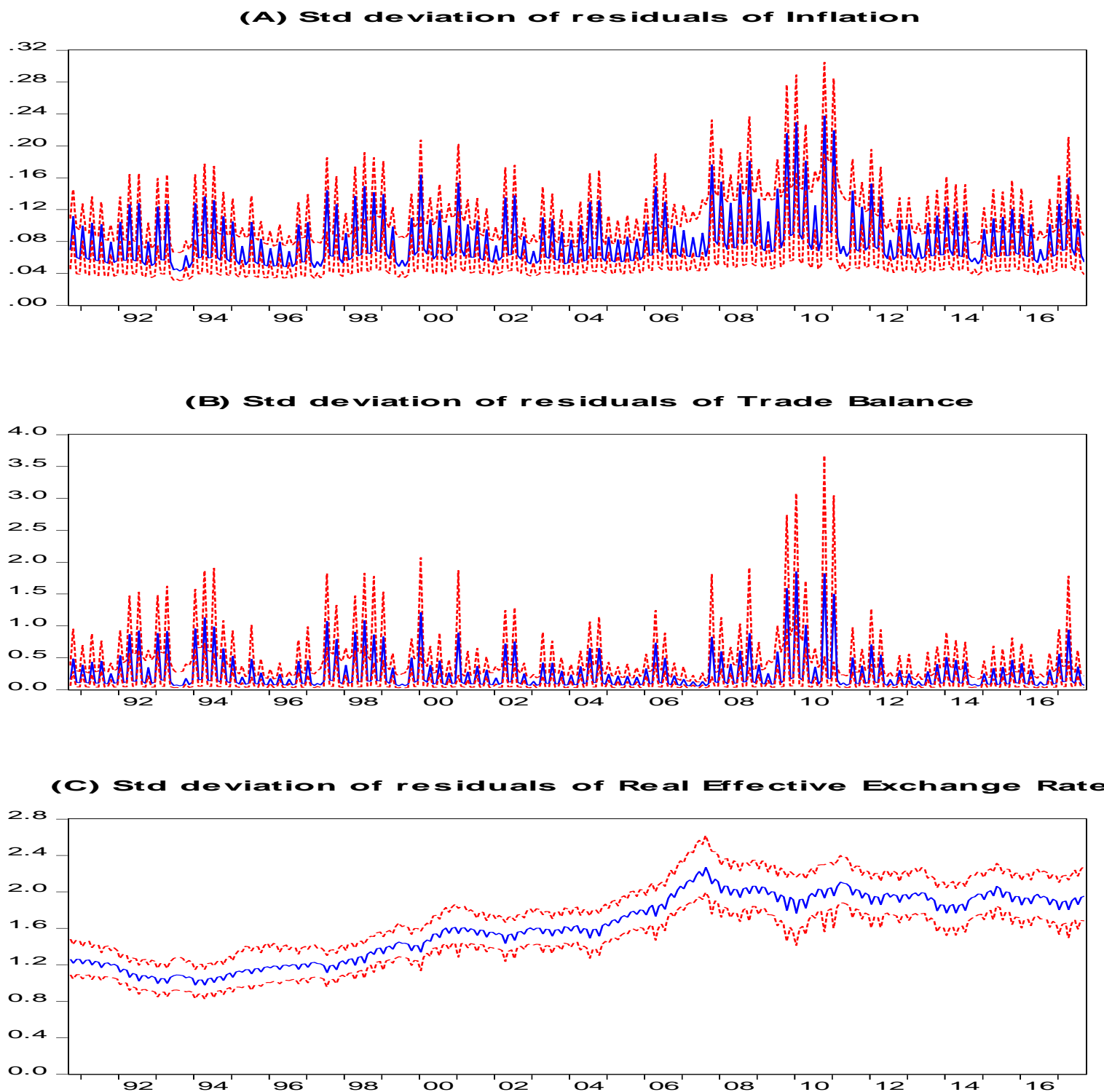

Figure 11: Posterior mean, $16^{\text {th }}$ and $84^{\text {th }}$ percentiles of the standard deviation of $(\mathrm{A})$ residual of the Inflation Rate (B) residual of the Trade Balance (\% of GDP) and (C) residuals of the equation for REER Shocks for New Zealand.

The Figure 11 (A-C C) and the results on the posterior mean of the standard deviation of residuals of all the series presented above showed that post-adoption of the inflation targeting, the volatility in inflation and trade balance has been fairly consistent and modest. There is an increase in the oscillations of residuals around the GFC in both inflation and trade balance which is also intuitive as the GFC brought a significant drop in the activity, inflation and global trade. Next, we come to analyse the ERPT to inflation, the results of the real effective exchange rate shocks and the response of inflation are summarised in Figure $12(\mathrm{~A}-\mathrm{E})$. 

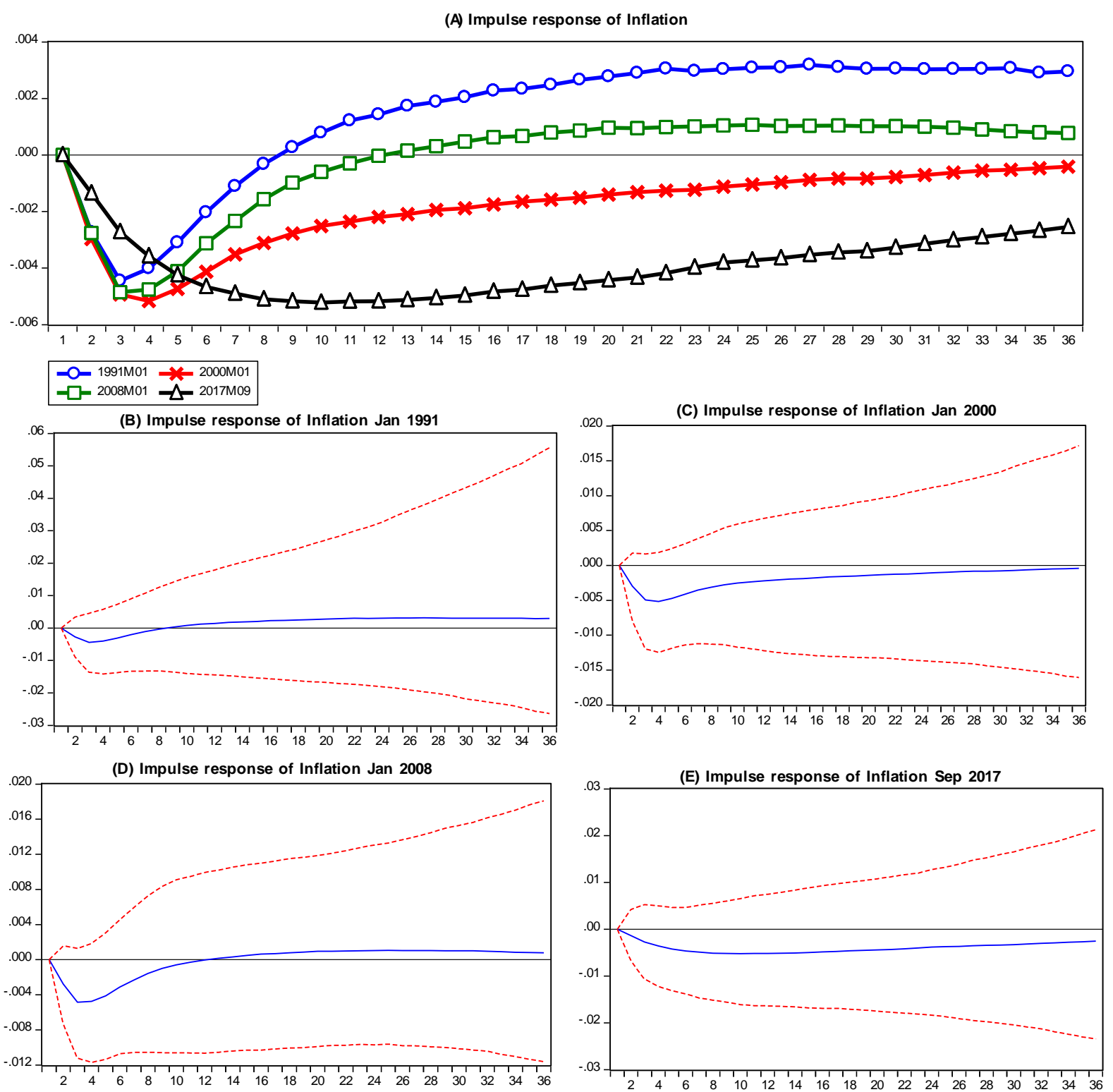

Figure 12: Response of Inflation to Exchange Rate Shocks, Jan 1991, 2000, 2008 \& September 2017(12A). Pairwise difference between the responses in corresponding periods with $16^{\text {th }}$ and $84^{\text {th }}$ percentiles $(12 B-E)$.

It showed that in response to the (positive) shock to the real effective exchange rate, the inflation in New Zealand fell. However, there is clear evidence of time-variation in the association between the exchange rate shocks and inflation; this time-variation is not in the direction but in the magnitude of the effect. It showed that in the earliest period (Jan 1991) inflation quickly recovered after exchange rate shock, however, in the later periods and particularly in the recent period, the exchange rate shock became even more pronounced and persistent. This implies that in New Zealand the ERPT has been increasing rather decreasing over time. After inflation, we analyse the impact of ERPT on New Zealand's trade balance and the results are presented as follows;- 


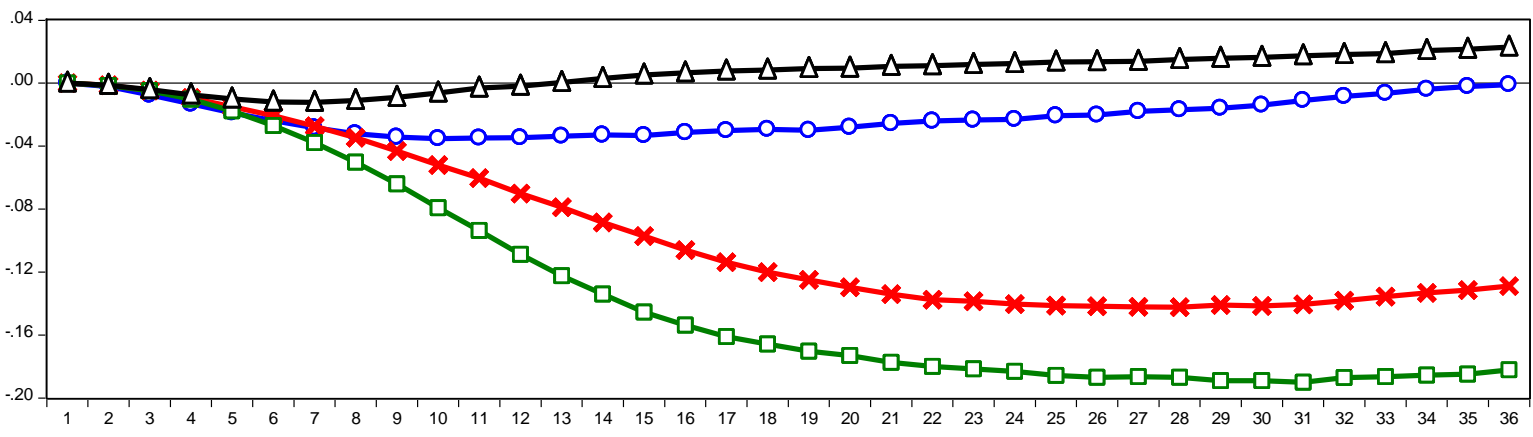

\section{- $1991 \mathrm{MD} 1-\mathrm{K}-2000 \mathrm{MD} 1$} $\square-2008 \mathrm{MD1}-\Delta-2017 \mathrm{ND9}$

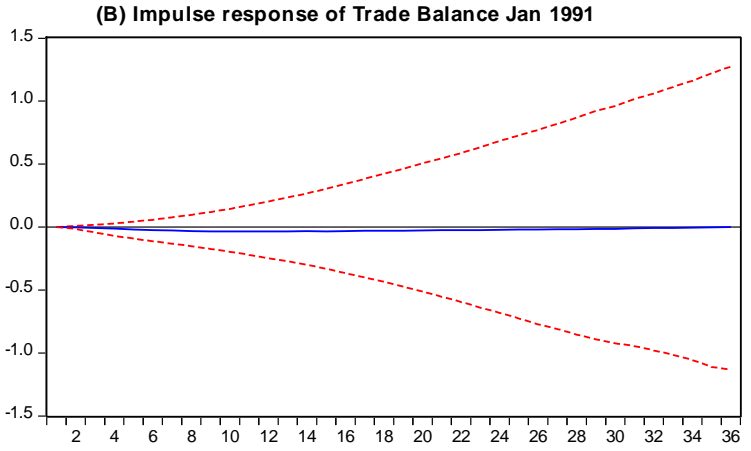

(C) Impulse response of Trade Balance Jan 2000

(D) Impulse response of Trade Balance Jan 2008
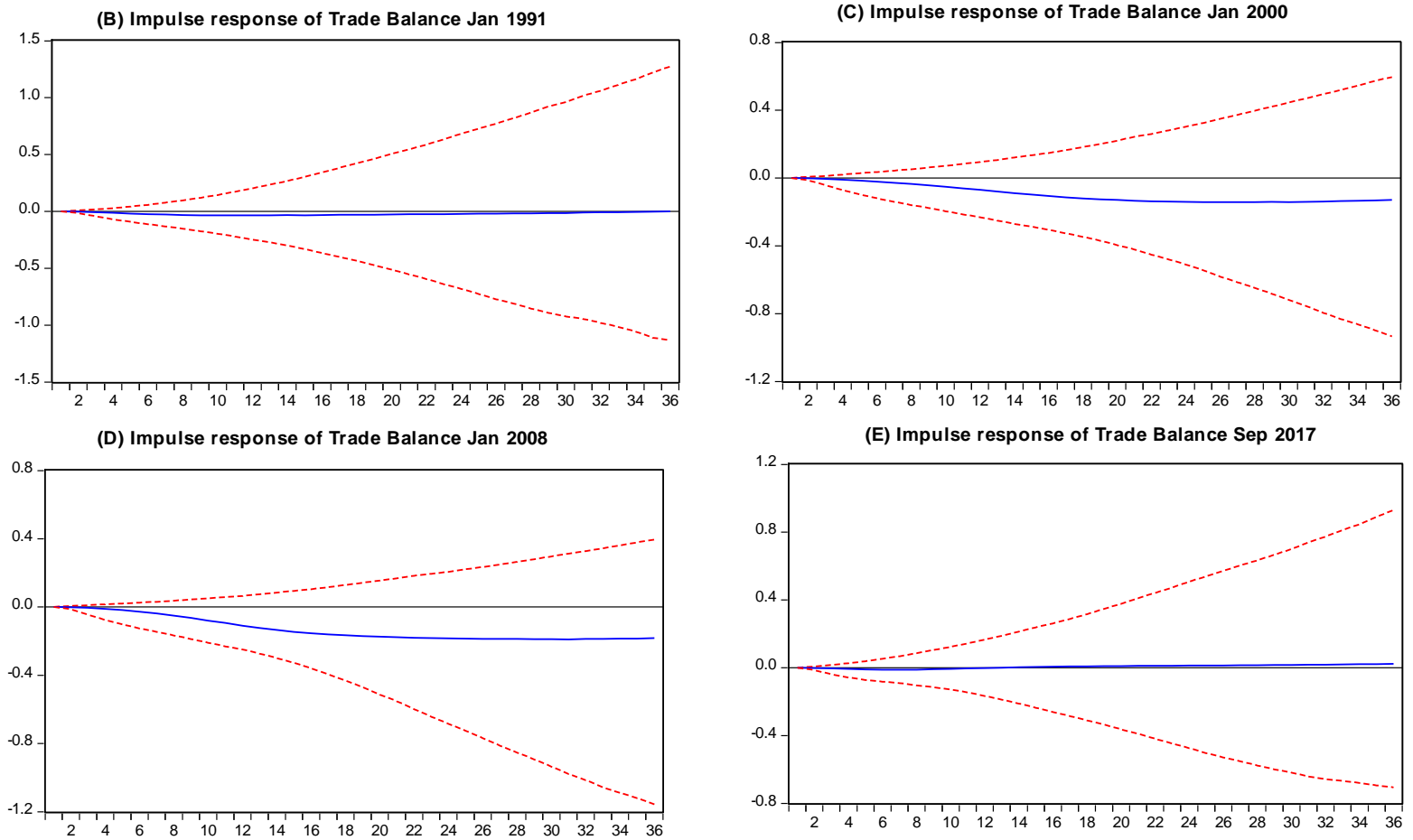

(E) Impulse response of Trade Balance Sep 2017

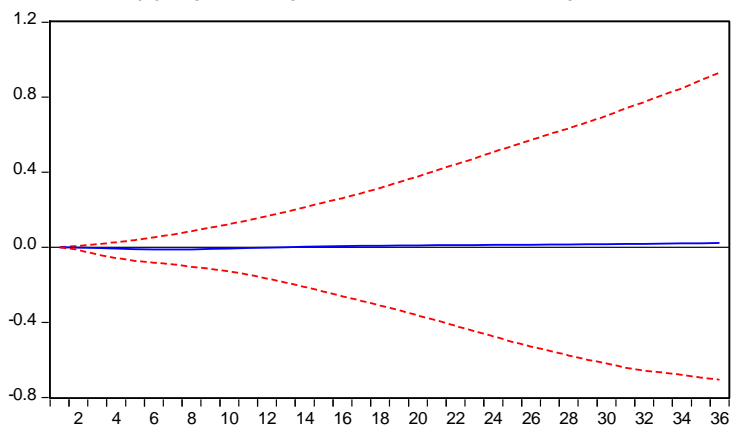

Figure 13: Response of New Zealand Trade Balance to Exchange Rate Shocks, Jan 1991, 2000,2008 \& September 2017(A). Pairwise difference between the responses in corresponding periods with $16^{\text {th }}$ and $84^{\text {th }}$ percentiles (13B-E).

The results for the ERPT to the New Zealand trade balance showed that a (positive) shock to the REER leads to deterioration of the trade balance of New Zealand. Furthermore, it showed that in the initial period the (Jan 1991) the impact was more persistent and prolonged. Nonetheless, around the GFC the results were more significant; however, there are also elements of time variation. In the latest periods, the impact became milder and insignificant. It leads us to conclude in the next section.

\section{Conclusion and Policy Implications}

In the context of adoption and practice of explicit inflation targeting strategy that was adopted over a Quarter of a century ago, we analysed the implication of the ERPT to Inflation and Trade balance. In so doing, we drew on the evidence form the first three adopters including New Zealand, Canada and the United Kingdom. Nonetheless, to incorporate and account for the time-variation in the association among the underlying variables of interest we employed a TVSVAR framework. The novelty of this framework is that it gives a deeper insight into the dynamics of the relationship among the economic entities which in the subject case were real effective exchange rate, inflation and trade balances of the 
respective countries. To begin with, we employed an ADF Unit root test with structural breaks (using innovation and additive outliers) on inflation datasets. The coefficients showed the beginning of a period of tranquillity in oscillations of coefficients which corresponded with the start of inflation targeting. This implied that there was evidence of a decrease in the volatility of inflation which one may associate with the start of inflation targeting or Great Moderation. However, in specific to the ERPT to inflation and trade balance, our results lead us to conclude that there was a significant element of time variation. Specifically, it showed that for the UK there was significant evidence of ERPT to inflation and trade balance. The positive REER shock which implies appreciation led to a positive effect on inflation before the BoE starting inflation targeting (January 1990). Interestingly, in the periods after the adoption of inflation targeting and independence of the BoE, there is a clear indication that the positive exchange rate shocks led to a significant drop in inflation. It implied that the inflation targeting and Bank of England independence have, in fact, come with the increase in the ERPT to inflation rather a decrease. In specific to the inflation, targeting our results contradicts the notion that the countries that have adopted inflation targeting may lead to a decline in the pass-through from exchange rate changes to inflation. The evidence suggests that the quarter-century of inflation targeting in the UK may have been successful in taming the inflation, however, the ERPT to inflation holds its grounds fairly strongly. Lastly, results also suggested that the ERPT has shown the highest impact in the latest period which corresponds to the monetary policy at ZLB. These findings support the notion by Forbes (2016 and 2017) that if anything ERPT has increased rather decreased over time. The results on ERPT to trade balance showed a prima facie manifestation of a J-curve behaviour. It also implies that the depreciation of Sterling could bring international competitiveness for the UK's economy and external balance. Furthermore, as we compared the Pre-inflation targeting period with the current period it suggests the relationship has even grown stronger. Hence, we conclude that the ERPT to trade balances under inflation targeting has not diminished and if anything, has increased.

We also found concrete evidence of country-level heterogeneity in the ERPT. The results on Canada showed that contrary to the UK, a positive shock to the REER led to an increase in the inflation in Canada in all of the under-analysis periods. The results imply that the appreciation of the currency in Canada puts upward pressure on inflation. Interestingly we see a significant element of time variation. In the Pre-Inflation targeting regime, the shock to inflation was more persistent and did not fade quickly. However, the results of the later periods suggested that despite the initial impact of the same magnitude, the inflation rate returns to its equilibrium value rather swiftly. This change in the inflation response and speed of adjustment to exchange rate shocks could be associated with the ability of the inflationtargeting regime which led to prompt adjustment rather than otherwise. The results on the Canadian trade balance showed that the positive shocks to the REER led to the deterioration of trade balance in all the periods. There was a subtle improvement in the trade balance in the beginning; however, it was not exactly like a J-curve. The comparison of the ERPT in different periods suggests some difference, specifically, in the later parts it suggests that the ERPT to the trade balance decreased in Canada.

Comparatively, New Zealand the pioneer of inflating targeting showed smaller magnetite of ERPT to inflation and trade balance as compared to its immediate followers. The results on New Zealand show that the in response to the REER shocks the inflation fell and there was clear evidence of time-variation in the magnitude of ERPT to inflation. There was also an increase in the magnitude of ERPT in the recent periods implying that the ERPT to inflation has increased in New Zealand. On the other hand, for the trade balance, in response to the exchange rate (positive) shock, the trade balance of New Zealand deteriorated. It was also evident that in the initial period, the impact was more persistent and prolonged. Nonetheless, around the GFC the results were more significant, yet in the latest periods, the impact became milder and insignificant. This implied that although the ERPT to inflation in New Zealand increased over time for the trade balance it was the other way round. On the whole, if we compare the three countries which were the first three movers that adopted the inflation targeting, there is prima facie evidence of time-variation in ERPT to inflation as well as the trade balance. It leads us to conclude that the argument that under inflation targeting ERPT has diminished, does not hold its ground 
in the face of evidence. Country-level heterogeneities and time-variations also make it challenging to prescribe robust and time-invariant policy prescriptions as well as projection. However, in terms of forecasting and optimal policy response, the appropriate and logical way would be to consider the contemporary parameters of ERPT at any given time which shall be expected to vary over-time. 


\section{References}

Ashgar, Z. Abid, I. (2007), Performance of lag length selection criteria in three different situations," MPRA Paper 40042, University Library of Munich, Germany.

Bahmani-Oskooee, M. Ratha, A. (2004), “The J-curve: a literature review”, Applied Economics,36 (13): 1377-1398.

Bahmani-Oskooee, M., Harvey, H. Hegerty, S.W. (2013), "Empirical tests of the Marshall-Lerner condition: a literature review", Journal of Economic Studies, 40 (3):411-443.

Bahmani-Oskooee, M. Hegerty, S.W. (2010), "The J- and S-curves: a survey of the recent literature", Journal of Economic Studies,37 (6):580-596.

Bahmani-Oskooee, M. Halicioglu, F. Ghodsi, S. H (2016), Asymmetric Effects of Exchange Rate Changes on British Bilateral Trade Balances, 18th Annual Conference of ETSG, Helsinki-Finland, September 8-10, 2016

Bahmani-Oskooee, M. Harvey, H. Hegerty, S. W. (2018), The real peso-dollar rate and US-Mexico industry trade: an asymmetric analysis, Scott Journal of Political Economy, 65: 350-389

Banerjee, A., Lumsdaine, R. L., Stock, J.H. (1992), "Recursive and Sequential Tests of the Unit Root and Trend-Break Hypothesis: Theory and International Evidence", Journal of Business and Economic Statistics, 10, pp. 271-287

Beaudry, P. Ruge-Murcia, F. (2017), Canadian inflation targeting, Canadian Journal of Economics/Revue canadienne d'économique,50 (5): 1556-1572.

Bhattacharya, P.S. Karayalcin, C. A. Thomakos, D. D. (2008), Exchange rate pass-through and relative prices: An industry-level empirical investigation, Journal of International Money and Finance, 27 (7): $1135-1160$.

Bernanke, B. S. Laubach, T. Mishkin, F.S. Posen, A. S. (2001), Inflation Targeting: Lessons from the International Experience, Princeton University Press.

Bernanke, B. S. (2003), "Constrained Discretion" and Monetary Policy, Remarks by Governor Ben S. Bernanke Before the Money Marketeers of New York University, New York, New York

Calvo, G.A. Reinhart, C.M. (2000), “Fixing for your life”, NBER Working Paper, 8006.

Campa, J. Goldberg, L. (2005). "Exchange rate pass-through into import prices", The Review of Economics and Statistics, 87(4), 679-690.

Carrière-Swallow, Y. Gruss, B. Magud, N. Valencia, F. (2016). "Monetary Policy Credibility and Exchange Rate Pass-Through", IMF Working Paper, No. 16/240.

Caselli, Francesca and Roitman, Agustin (2016), "Non-Linear Exchange Rate Pass-Through in Emerging Markets", IMF Working Paper, No. 16/1

Choudhri, E. Hakura, D. (2006). "Exchange Rate Pass-Through to Domestic Prices: Does the Inflationary Environment Matter?" Journal of International Money and Finance 25(4): 614-639.

Comunale, M. Kunovac, D. (2017). "Exchange Rate Pass-Through in the Euro Area", ECB Working Paper, No. 2003 / January 2017.

Del Negro, M. Primiceri, G. E. (2015), Time Varying Structural Vector Auto regressions and Monetary Policy: A Corrigendum, The Review of Economic Studies, 82(4) pp. 1342-1345.

Dornbusch, R. (1987). "Exchange rates and prices”, American Economic Review, 77, 93-106.

Edwards, S. (2007), The Relationship Between Exchange Rates and Inflation Targeting Revisited, NBER Working Paper No. 12163 
Eichengreen, B. (2002) can emerging markets float? Should they inflation target? Central Bank of Brazil, Working Paper No. 36.

Federal Reserve (2018), What is the statement on longer-run goals and monetary policy strategy and why does the Federal Open Market Committee put it out? Available at https://www.federalreserve.gov/faqs/statement-on-longer-run-goals-monetary-policy-strategy-

fomc.htm accessed at 10th January 2018.

Fisher, S. (2015). US inflation developments, Speech given at the Federal Reserve Bank of Kansas City Economic Symposium, Jackson Hole on August 29, 2015.

Fleer, R., Rudolf, B. Zurlinden, M. (2015). Price Change Dispersion and Time-Varying Pass-Through into Consumer Prices, mimeo.

Forbes, K. (2015b). When, Why, And Whats Next For Low Inflation?: No Magic Slippers Needed, Speech given at the London School of Economics on June 17, 2015.

Forbes, K. (2016). Much Ado About Something Important: How Do Exchange Rate Movements Affect Inflation? The Manchester School, 84 No. S1 15-41

Forbes, Kristin, Hjortsoe, Ida, Nenova, Tsvetelina (2015). "The Shocks Matter: Improving our Estimates of Exchange Rate Pass-Through", Bank of England External MPC Unit Discussion Paper, No. 43.

Forbes, K. (2015). Risks around the Forecast, Speech given in London on January 22, 2015.

Forbes, K. Hjortsoe, I. Nenova, T. (2017), Shocks versus Structure, explaining difference in exchange rate pass-through across countries and time, Bank of England, Discussion Paper N. 50.

Forbes, K. Kirkham, L. Theodoridis, K. (2017). "A Trendy Approach to US Inflation Dynamics", Bank of England External MPC Working Paper \#49, June.

Fox, A.J. (1972), Outliers in Time Series", Journal of the Royal Statistical Society, B, 34, pp. 350363.

Fraga, A. Goldfajn, I. Minella, A. (2003), Inflation Targeting in emerging market economies. In:

Gertler, Mark; Kenneth, Rogoff (Orgs.) NBER Macroeconomics annual, 18. MIT Press, pages 365400 .

Frankel, J. (2012), The Death of Inflation Targeting, Project Syndicate, available at https://www.project-syndicate.org/commentary/the-death-of-inflation-targeting accessed on 10th January 2018.

Gagnon, J. Ihrig, J. (2004). “Monetary Policy and Exchange Rate Pass-Through”, International Journal of Finance \& Economics, 9(4): 315-338.

Goldberg, P. K. Knetter, M. M. (1997). Goods prices and exchange rates: What have we learned? Journal of Economic Literature, 35, pages 1243-1272.

Goldfajn, I. Werlang, S. (2002) The pass-through from depreciation to inflation: a panel study.

Central Bank of Brazil, (Working Paper n. 05).

Gopinath, G. (2015). The International Price System, Federal Reserve Bank of Kansas City Economic Symposium, Jackson Hole.

Ghosh, A. Wolf, H. (2001). "Imperfect Exchange Rate Passthrough: Strategic Pricing and Menu Costs," CESifo Working Paper Series 436, CESifo Group Munich.

Ha, Jongrim; Stocker, Marc; Yilmazkuday, Hakan. 2019. Inflation and Exchange Rate Pass-Through, Policy Research working paper; no. WPS 8780. Washington, D.C.: World Bank Group. 
Haldane, A. G. (1995). Targeting Inflation: A Conference of Central Banks on the Use of Inflation Targets Organised by the Bank of England, 9-10 March 1995. London: Bank of England.

Hume, D. (1742), Essays, Moral, Political, and Literary, Edinburgh: A. Kincaid.

IMF (2017), Inflation Targeting: Holding the Line, available at http://www.imf.org/external/pubs/ft/fandd/basics/target.htm accessed on 9th January 2018.

Jasová, M. Moessner, R. Takáts, E. (2016). "Exchange Rate Pass-Through: What Has Changed Since the Crisis?", BIS Working Paper, No. 583.

Junior, R.P.N. (2007), Inflation targeting and exchange rate pass-through, Economia Aplicada,11 (2): 189-208.

Klein, M. (1990). "Macroeconomic Effects of Exchange Rate Pass-Through", Journal of International Money and Finance, vol. 9 (4), 376-387.

Krugman, P (1987). "Pricing to Market When the Exchange Rate Changes", in Real-Financial Linkages among Open Economies, edited by Sven W. Arndt and J. David Richardson. Cambridge, Mass, MIT Press.

Lee, J. (1997), The Response of Exchange Rate Pass-Through to Market Concentration in a Small Economy: The Evidence from Korea, Review of Economics and Statistics, 79 (1), pp.142-145.

Marazzi, M. Sheets, N. Vigfusson, R. J. Faust, J. Gagnon, J., Marquez, J. Martin, R. F. Reeve, T. and Rogers, J. (2005). Exchange Rate Pass-Through to U.S. Import Prices: Some New Evidence, International Finance Discussion Papers 833, Board of Governors of the Federal Reserve System (U.S.).

Menon, J. (1995). Exchange rate pass-through. Journal of Economic Surveys, 9, 197-231.

Mishkin, F. Savastano, M. (2001), Monetary policy strategies for Latin America. Journal of Development Economics, 66, : 415-444.

Mishkin, F. S. (2010), Inflation Targeting in Emerging Market Countries, NBER Working Paper No. w7618.

Mishkin, F.S. (2016), The Economics of Money, Banking and Financial Markets, Global Edition, Pearson Education Limited, Harlow, United Kingdom.

Mumtaz, H., Oomen, O. Wang, J. (2006). Exchange Rate Pass-Through into UK Import Prices, Bank of England Working Paper No. 312.

Nasir, M. A. (2017), Zero Lower Bound \& Negative Interest Rates: Choices for the Monetary Policy (February 3, 2017). Available at SSRN: https://ssrn.com/abstract=2881926 or http://dx.doi.org/10.2139/ssrn.2881926

Nasir, M. A. Simpson, J. (2018) Brexit Associated Sharp Depreciation and Implications for UK's Inflation and Balance of Payments, Journal of Economic Studies, 45 (2): 231-246.

Nasir, M. Morgan, J. (2018), "Pre-Brexit: The EU referendum as an illustration of the effects of uncertainty on the Sterling exchange rate", Journal of Economic Studies, 45(5): 910-921.

Nasir, M. A. Balsalobre-Lorente, D. Huynh, T.L.D. (2020a), Anchoring inflation expectations in the face of oil shocks \& in the proximity of ZLB: A tale of two targeters, Energy Economics, 86,104662.

Nasir, M. A. Huynh, T.L.D. Vo, X. V., (2020b) Exchange Rate Pass-Through \& Management of Inflation Expectation in a Small Open Inflation Targeting Economy (April 24, 2019). Available at SSRN: https://ssrn.com/abstract=3377181

Nasir, M. A. Huynh, T.L.D. Yarovaya, L. (2020c), Inflation targeting \& implications of oil shocks for inflation expectations in oil importing and exporting economies: Evidence from three Nordic Kingdoms, the $4^{\text {th }}$ Vietnam Symposium in Banking and Finance (VSBF:2019) 
Obstfeld, M. (2014), Never Say Never: Commentary on a Policymaker's Reflections, IMF Econ Review, 62: 656.

Ozyurt, S. (2016). "Has the Exchange Rate Pass-Through Recently Declined in the Euro Area?", ECB Working Paper, No. 1955/September 2016

Pourroy, M. (2012), Does exchange rate control improve inflation targeting in emerging economies? Economics Letters, 116, pp. 448-450.

Primiceri, G. E. (2005) “Time Varying Structural Vector Auto-regressions and Monetary Policy,” The Review of Economic Studies, 72 (3), pp. 821-852.

Negro, M. D. Primiceri, G. E. (2015), Time Varying Structural Vector Autoregressions and Monetary Policy: A Corrigendum, The Review of Economic Studies,82 (4), pp. 1342-1345.

Riboni, A. Ruge-Murcia, F. (2018), Monetary policy committees: Voting and deliberation, in Hawks and Doves: Deeds and Words, S. Eijffinger and D. Masciandaro (Eds.), pp. 75-80, with A. Riboni. London: CEPR Press.

Rose, A.K. Yellen, J.L. (1989), “Is there a J-curve?”, Journal of Monetary Economics, 24 (1): 53-68.

Rose, A. K (1990), Exchange rates some evidence from and the trade balance developing countries, Economic Letters, 34, 172-275.

Rose, A. K (1991), The role of exchange rates in a popular model of international trade: Does the 'Marshall-Lerner' condition hold? Journal of International Economics, 30 (3-4): 301-316.

Ruge-Murcia, F.J. (2002). "Some Implications of the Zero Lower Bound on Interest Rates for the Term Structure and Monetary Policy." Centre de recherche et développement en économique (CRDE) Working Paper No. 06-2002.

Ruge-Murcia, F. J, (2003). "Inflation Targeting under Asymmetric Preferences," Journal of Money, Credit and Banking, 35(5): 763-785.

Ruge-Murcia, F. J. (2004). "The inflation bias when the central bank targets the natural rate of unemployment," European Economic Review: 48(1), 91-107.

Ruge-Murcia, F (2010). “The Zero Lower Bound on Interest Rates and Monetary Policy in Canada, Bank of Canada Working paper, available at https://www.bankofcanada.ca/wpcontent/uploads/2010/08/murcia.pdf

Schmidt-Hebbel, K. Werner, A. (2002) inflation targeting in Brazil, Chile and Mexico: performance, credibility and the exchange rate. Central Bank of Chile, Working Paper No 171.

Sims C. A. T. ZHA (2006), "Were There Regime Switches in US Monetary Policy? American Economics Review, 96 (1): 54-81.

Smith, M. Kohn, R. (2002), "Parsimonious Covariance Matrix Estimation for Longitudinal Data", Journal of the American Statistical Association, 97, pp. 1141-1153.

Stulz, J. (2007) Exchange Rate Pass-Through in Switzerland: Evidence from Vector Autoregressions, Swiss National Bank Economic Studies, No. 4.

Taylor, J. (2000). "Low inflation, pass-through and the pricing power of firms", European Economic Review 44(7): 1389-1408.

Tsay, R.S. (1988). Outliers, Level Shifts and Variance Changes in Time Series. Journal of Forecasting. 7, 1-20.

Vogelsang, T and P. Perron, (1998), "Additional Tests for a Unit Root Allowing for a Break in the Trend Function at Unknown Time", International Economic Review, 39, 1073-1100. 
Williams, J.C. (2014), Inflation Targeting and the Global Financial Crisis: Successes and Challenges, Conference on Fourteen Years of Inflation Targeting in South Africa and the Challenge of a Changing Mandate.

Yildirim, Z. Ivrendi, M. (2016), Exchange rate fluctuations and macroeconomic performance, Journal of Economic Studies, 43 (5): 678-698.

Yetman, J. (2017), The evolution of inflation expectations in Canada and the US. Canadian Journal of Economics/Revue canadienne d'économique, 50 (3):711-737.

Zivot, E. and Andrews, K. (1992), "Further Evidence on The Great Crash, The Oil Price Shock, and The Unit Root Hypothesis", Journal of Business and Economic Statistics, 10 (10), pp. 251-70. 
